\title{
The Lake Clear (41SM243) Site and Crotalus horridus atricaudatus
}

Mark Walters

Heritage Research Center, Stephen F. Austin State University

Follow this and additional works at: https://scholarworks.sfasu.edu/ita

Part of the American Material Culture Commons, Archaeological Anthropology Commons, Environmental Studies Commons, Other American Studies Commons, Other Arts and Humanities Commons, Other History of Art, Architecture, and Archaeology Commons, and the United States History Commons

Tell us how this article helped you.

This Article is brought to you for free and open access by the Center for Regional Heritage Research at SFA ScholarWorks. It has been accepted for inclusion in Index of Texas Archaeology: Open Access Gray Literature from the Lone Star State by an authorized editor of SFA ScholarWorks. For more information, please contact cdsscholarworks@sfasu.edu. 


\section{The Lake Clear (41SM243) Site and Crotalus horridus atricaudatus \\ Creative Commons License \\ (c) (1) (9)}

This work is licensed under a Creative Commons Attribution-NonCommercial 4.0 International License 


\title{
The Lake Clear (41SM243) Site and Crotalus horridus atricaudatus
}

\author{
Mark Walters
}

\section{INTRODUCTION}

I fell heir to a collection of prehistoric Caddo sherds from my late Uncle Sam Whiteside and a location on a 7.5' topographic map labeled Lake Clear. Sam Whiteside during the period from the mid-1950s to the late 1960s was very active in the East Texas area working through the old East Texas Archeological Society headquartered in Tyler, Texas (Walters 2005).

The name Lake Clear was vaguely familiar but a check of local maps failed to reveal its location. However, an older map jolted my memory. The lake had been built on east Mill Creek west of Winona, Texas, as a club lake. For some reason, the project was abandoned after a short period of time and the lake was drained and turned into pasture. Although I have never even visited the site location, but did record it in 2000, I felt that writing this article was justified in order to (1) describe this interesting collection of Caddo sherds and (2) compare one aspect of the sherds - the engraved rattlesnake motif found on several Lake Clear sherds - to other known examples in the Caddo archeological area. This was not a new idea but had been hashed around in prior years by Tim Perttula, Tom Middlebrook, and the late Jim Corbin (1997), among others (see Galan 1994). Tim Perttula was especially helpful in sharing his notes. Perhaps the most important part of research is knowing when to stop. I realize that other examples of the rattlesnake motif in Caddo pottery will appear in the future, hopefully spurred on by this article, and if someone else would like to take up the subject where I have left off, I would be pleased.

\section{LOCALITY}

The Lake Clear site (41SM243) is located on East Mill Creek in northern Smith County, Texas. East Mill Creek drains into the Sabine River $2.5 \mathrm{~km}$ to the north. East Mill Creek heads around the Red Springs community (7.5 km west of the Lake Clear site) in an area characterized by steep slopes and gravelly Redsprings-Cuthbert-Elrose soils with glauconitic materials. Soils in the Lake Clear site area are Oakwood-Cuthbert loamy soils with a loamy or clayey subsoil (see Hatherly 1993: Map 9). The Jamestown site (41SM54), a probable Middle Caddoan period (ca. A.D. 1200-1400) mound center with seven mounds, is located some $40 \mathrm{~km}$ to the northwest on Village Creek and approximately the same distance south of the Sabine River. The Boxed Springs site (41UR30), thought to date to the Early Caddoan time period (ca. A.D. 900-1200), is located approximately $15 \mathrm{~km}$ to the east, on the north bank of the Sabine River (Perttula et al. 2000). It is interesting to note that later Caddo groups choose to live on small tributaries off of main streams, usually in an upland setting (see Walters and Haskins 1998, 2000). 


\section{Artifact Inventory from the Lake Clear Site (41SM243)}

A total of 119 artifacts are in the collections from the Lake Clear site (Table 1). All are made of clay. They include 117 ceramic sherds, a clay figurine, and one clay pipe stem.

No written record remains of the type or extent of excavations that were carried out at the Lake Clear site, so it is assumed that all excavations were uncontrolled. Since only decorated sherds or plain rims from ceramic vessels were collected (see Table 1), nothing is known about the abundance of plain sherds, nor can we compute the plain to decorated sherd ratio (which has been shown to have some chronological significance in Caddo ceramic assemblages in parts of northeastern Texas). The following analysis of the artifacts collected reflects this lack of chronological control for the Caddo occupation at the Lake Clear site, though it is thought to have been occupied sometime during the Middle Caddoan period.

Table 1. Artifacts from the Lake Clear site.

\begin{tabular}{ll}
\hline Artifact Class & No. of Specimens \\
\hline & \\
Decorated sherds & 111 \\
Plain rims & 6 \\
Clay figurine & 1 \\
Clay pipe stem & 1 \\
\hline Total artifacts & 119 \\
\hline
\end{tabular}

\section{DECORATED SHERDS}

The 111 decorated sherds primarily include sherds from vessels with incised, brushed, engraved, and punctated decorative elements (Table 2). These four decorative elements comprise more than $85 \%$ of all the decorated sherds from the Lake Clear site.

There are minor amounts of brushed, brushed-punctated, and pinched-ridged sherds in the assemblage, but these represent less than $15 \%$ of the decorated sherds (see Table 2). Combining the brushed and brushed-punctated sherds, more than $30 \%$ of all the decorated sherds from the Lake Clear site have brushing on them. The relative frequency of brushed-punctated sherds is interesting, given the findings from the Oak Hill Village site that brushed-punctated sherds were most common in the post-A.D. 1350 Late Vilage occupation there (Rogers and Perttula 2004).

More than $94 \%$ of the sherds from the site are tempered with grog, but in many cases, the grog temper was supplemented with the addition of burned bone pieces (Table 3). Only a few sherds have pieces of grit deliberately added to the paste of the Lake Clear vessels. 
Table 2. Decorated sherds from the Lake Clear site.

\section{Decoration}

No. Percentage

\begin{tabular}{lll}
\hline Incised & 31 & 27.9 \\
Brushed & 29 & 26.1 \\
Engraved & 20 & 18.0 \\
Punctated/incised & 15 & 13.5 \\
Punctated & 9 & 8.1 \\
Brushed/punctated & 5 & 4.5 \\
Pinched/ridged & 2 & 1.8 \\
\hline
\end{tabular}

$\begin{array}{lll}\text { Totals } & 111 & 99.9\end{array}$

Table 3. Temper in the Lake Clear ceramics.

\begin{tabular}{llllll}
\hline Decoration & Bone & Bone/grog & $\begin{array}{l}\text { Bone/grog/ } \\
\text { grit }\end{array}$ & Grog & Grog/grit \\
\hline Incised & 1 & 16 & - & 14 & - \\
Brushed & 5 & 15 & - & 9 & - \\
Engraved & - & 9 & - & 9 & - \\
$\begin{array}{l}\text { Punctated/incised } \\
\text { Punctated }\end{array}$ & - & 4 & 2 & 9 & - \\
Brushed/punctated & 1 & 2 & - & 5 & 1 \\
Pinched/ridged & - & 1 & - & 2 & - \\
Plain rims & - & 4 & - & 1 & - \\
\hline & 7 & 54 & - & 2 & - \\
Totals & 5.9 & 46.2 & 1.7 & 53 & 1 \\
Percentage & & & & 44.9 & 0.8 \\
\hline
\end{tabular}


Bone was present as a temper in $53.8 \%$ of the sherds, but only $5.9 \%$ of the Lake Clear sherds were tempered solely with bone (see Table 3). The incised, brushed, and brushed-punctated sherds tended to be from vessels that were more frequently tempered with bone, either by itself as the sole temper, or with grog.

The vessels made and used at the Lake Clear site are relatively thick, as the mean thickness of all the sherds is $7.9 \mathrm{~mm}$ (Table 4). The utility ware sherds are thicker on average (ranging from 7.2-9.1 $\mathrm{mm}$ ) than either the engraved fine wares or the plain rims.

More than $76 \%$ of the sherds from the Lake Clear site are from vessels that were fired in a low oxygen or reducing environment (Table 5), and the remainder were fired in a high oxygen or oxidizing environment. This is the case for the fine wares, the utility wares, and the plain rims, but the engraved vessels tend to have higher frequencies of reduced-firing vessels than the utility wares (with the exception of the brushed-punctated and pinched-ridged sherds).

Among the vessels sherds from vessels fired in a reducing environment, most of them were fired and then also cooled in a low oxygen environment (see Table 5). However, $37 \%$ are from vessels that were fired in a low oxygen environment, but then pulled from the fire to cool in the open air. Proportionally, most of these sherds are from engraved vessels, punctated-incised vessels, and incised vessels (see Table 5).

\section{Incised Sherds}

There were 31 incised sherds (19 body and 12 rim) in the Lake Clear collection. Fourteen of the 31 sherds had one or more straight parallel lines, some of these with very broad incised marks. Eleven sherds had opposing straight lines and six others had some form of cross-hatching (Figure 1a-b). None had obvious curvilinear designs. Of the 12 rims, eight had rounded lips and four were flattened. There were two everted rims and the remainder were straight or vertical in profile. The average thickness of the incised sherds was $7.2 \mathrm{~mm}$ (see Table 4), which is slightly thinner than the average thickness of all the sherds from the site $(7.9 \mathrm{~mm})$. Incised sherds, along with those with brushed decorations, had a higher percentage of bone temper than the other kinds of decorated sherds (see Table 3).

\section{Engraved Sherds}

There were 20 engraved sherds, including eight rims. Among the 20 engraved sherds are four body sherds and a rim sherd that have rattlesnake designs. These will be discussed separately below.

Looking at the other engraved body sherds, engraved sherd \#1 is from a large bottle represented by several large and relatively thick sherds (7.9 mm thick) (Figure 2$)$. The design on this vessel is comprised of straight opposing lines with branching curvilinear ladders. There is a white kaolin clay pigment in the lines.

Engraved sherd \#2 is also from a bottle (Figure 3). There is a horizontal line at the juncture of the bottle neck and body, and from this line there are concentric circular designs (filled with hatched lines). Part of the design forms a starburst. There is evidence of red pigment in the lines. This sherd strongly resembles a sherd found at the Middle Caddoan period Langford site (41SM197), located approximately $12 \mathrm{~km}$ away, but also on the south side of the Sabine River (Walters 1997).

Engraved sherd \#3 is from a carinated bowl. Beginning at the carination point, there are concentric engraved lines forming incomplete circles as well as diagonal lines with lines connecting them and also extending perpendicular from them. Engraved sherd \#4 has a circle formed by rough parallel lines, and engraved sherd \#5

\section{Spring 2006}


Table 4. Sherd Thickness.

\begin{tabular}{ll}
\hline Sherd Decoration & mean thickness $(\mathrm{mm})$ \\
\hline & 6.9 \\
Engraved & 7.1 \\
Plain rims & 7.2 \\
Incised & 7.8 \\
Pinched/ridged & 8.1 \\
Punctated/incised & 8.2 \\
Punctated & 8.4 \\
Brushed & 9.1 \\
Brushed/punctated & \\
\hline
\end{tabular}

Table 5. Firing Conditions in the Lake Clear sherds.

\begin{tabular}{lllll}
\hline Decoration & Reduced & Oxidized & \multicolumn{2}{l}{$\begin{array}{l}\text { Reduced but cooled in: } \\
\text { Low Oxygen }\end{array}$} \\
& & & & \\
& & & & \\
& & 10 & 12 & 3 \\
Incised & 21 & 5 & 8 & 3 \\
Brushed & 24 & 3 & 6 & 6 \\
Engraved & 17 & 3 & 2 & 2 \\
Punctated/incised & 12 & 5 & 3 & 2 \\
Punctated & 4 & - & 1 & 1 \\
Brushed/punctated & 5 & - & 3 & 1 \\
Pinched/ridged & 2 & 2 & & 33 \\
Plain rims & 4 & & 56 & 37.1 \\
& & & & \\
\hline
\end{tabular}




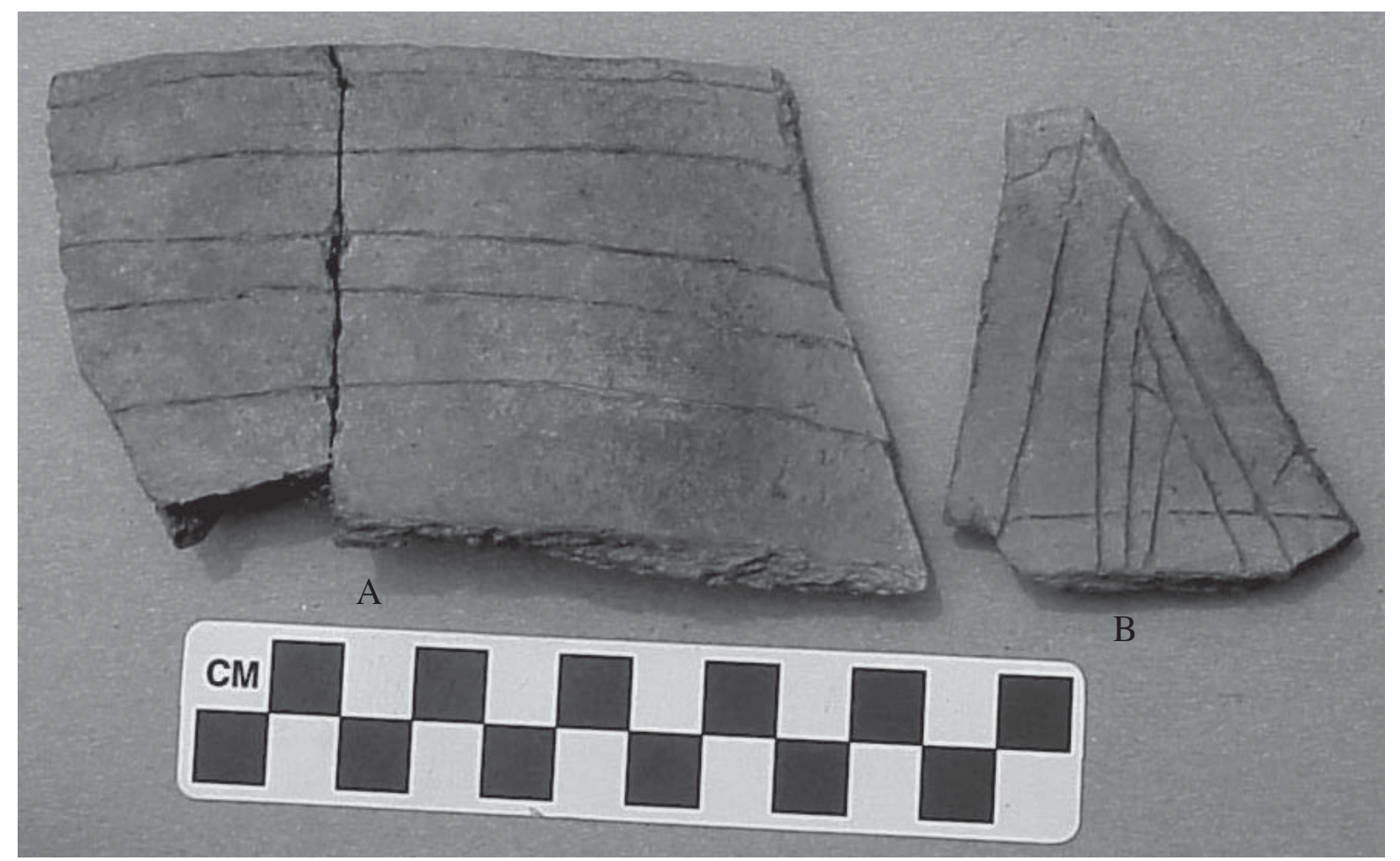

Figure 1. Incised sherds: a. Incised rims; b. Incised body sherds.

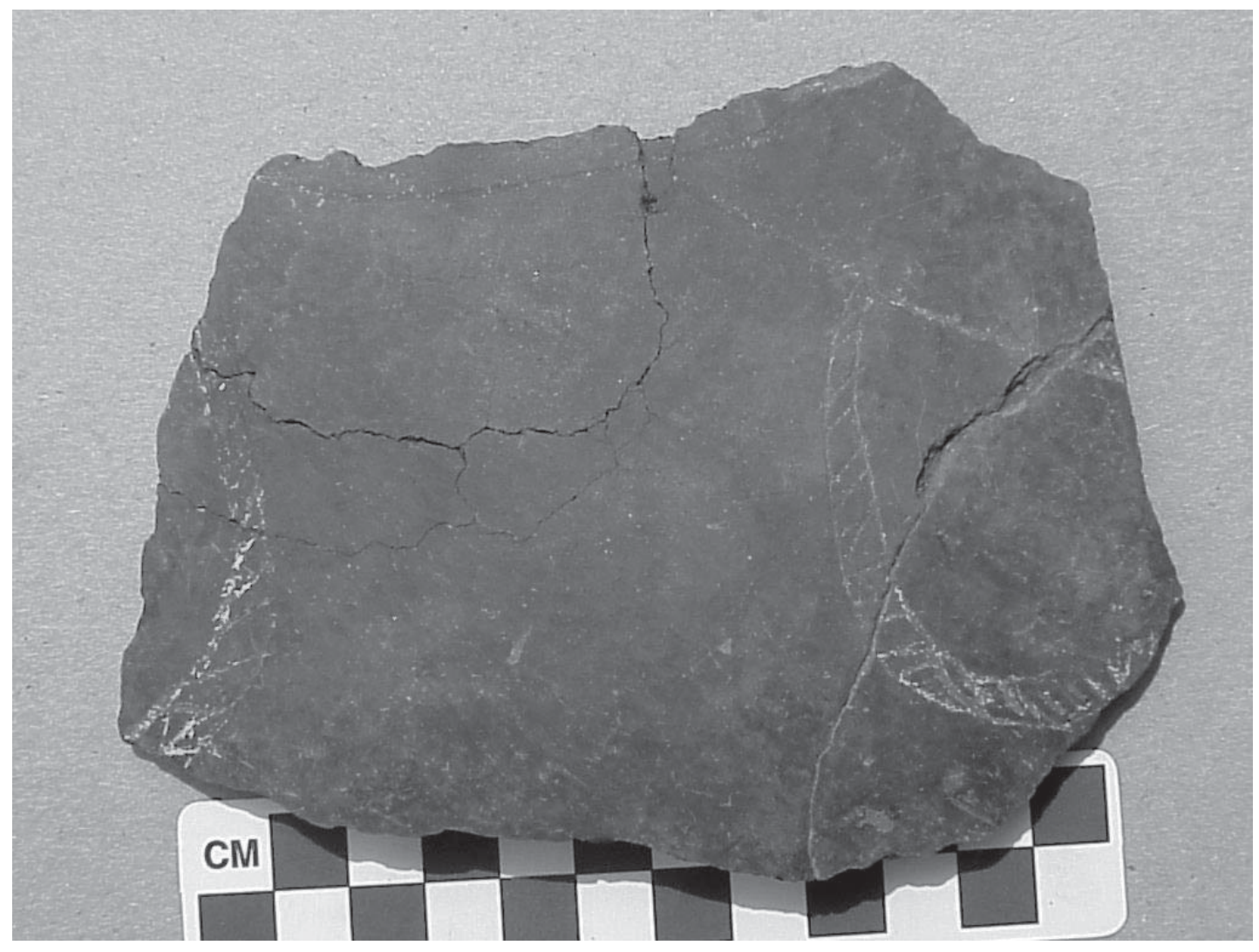

Figure 2. Engraved bottle sherd. 


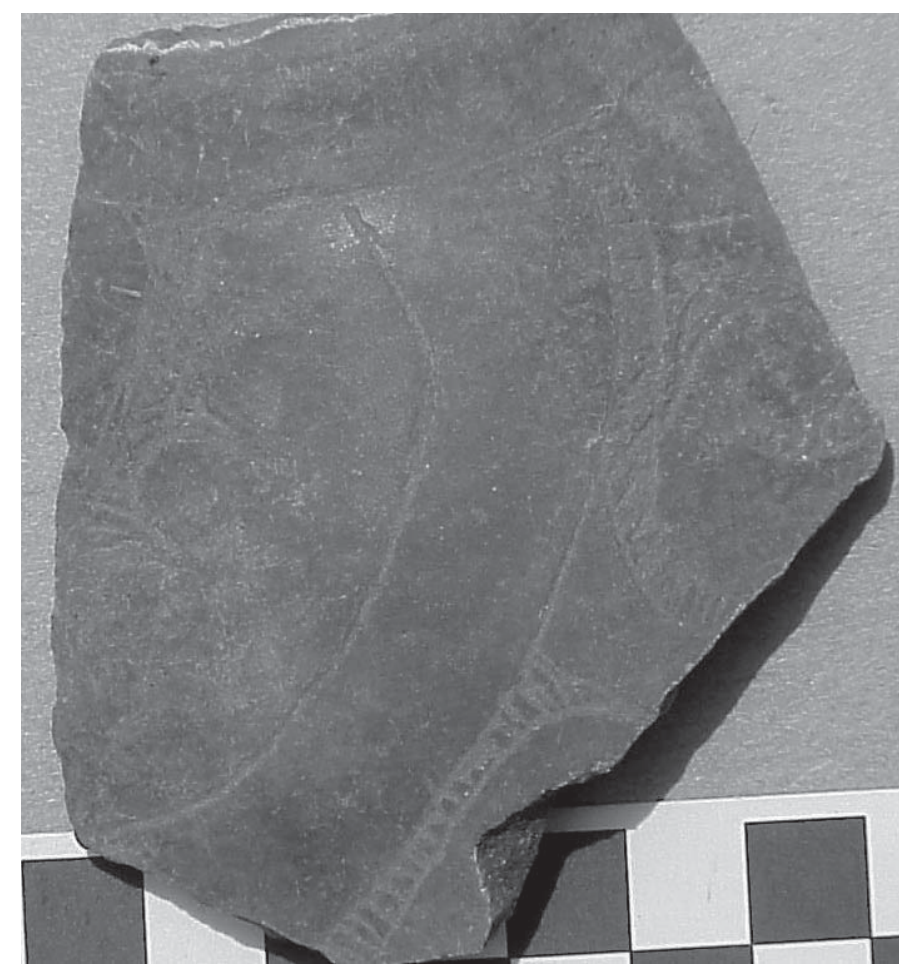

Figure 3. Engraved bottle with starburst design. has faint parallel and straight lines. Sherd \#6 also has parallel lines, and one of the lines has triangular-shaped bursts pendant from it. Engraved sherd \#7 is red-slipped and has parallel lines with pendant triangles. Engraved sherd \#8 has a single line with an attached opposed ladder design.

Looking at the engraved rims, the first rim (\#1) (Figure 4) has a top and bottom line containing panels with triangles that are defined by lines in all the corners. Vertical lines that have alternating concentric circles separate these panels. This design is very similar to Poynor Engraved "PO" decorative styles defined by Kleinschmidt (1982). This sherd has a straight rim with a rounded lip.

Engraved rim \#2 has a circle on it that is enclosing a crossed-arm design (Figure 5). Rim \# 3 has thin parallel horizontal engraved lines, while engraved rim \#4 is from a carinated bowl

with a straight $4 \mathrm{~cm}$ high rim and round lip. There are a series of opposing straight lines running from the lip. Engraved rim \#5 is a carinated bowl with a $1.5 \mathrm{~cm}$ high straight rim and with a single curved line running horizontally around the vessel. Rim \#6 has a direct rim with a flattened lip. The design consists of two horizontal lines with diagonal lines running between and opposing vertical lines. Engraved rim \#7 has a straight profile with a rounded lip, thinned on the inside. It is decorated with opposing straight lines.

\section{Brushed Sherds}

There were 29 brushed sherds, including three rims. The three rims had rounded lips, and one has been slightly rolled out. Another rim was everted, with a horizontal brushed decoration.

\section{Punctated/incised Sherds}

There were 15 punctated/incised sherds at Lake Clear, including two rims (Figures 6 and 7). Most of the designs consist of straight parallel incised lines with zones of punctates in the voids between the lines. Some of these incised lines were broad with drag marks, suggesting a broken stem was used to make the marks. The punctates were tear-dropped $(\operatorname{tn}=9)$, finger-nail or crescent $(n=3)$, or triangular $(n=3)$. One interesting sherd (see Figure 6a) had a row of small triangular punctates encased inside horizontal incised lines at the body juncture of a vessel with diagonal rows of incised ladders. Another example had a wide incised line with drag marks and a row of small triangular punctuates inside the line. The thickness of the punctated/incised sherds ranged from $5.8 \mathrm{~mm}$ to $10.2 \mathrm{~mm}$ with an average thickness of $8.07 \mathrm{~mm}$ (see Table 4). 


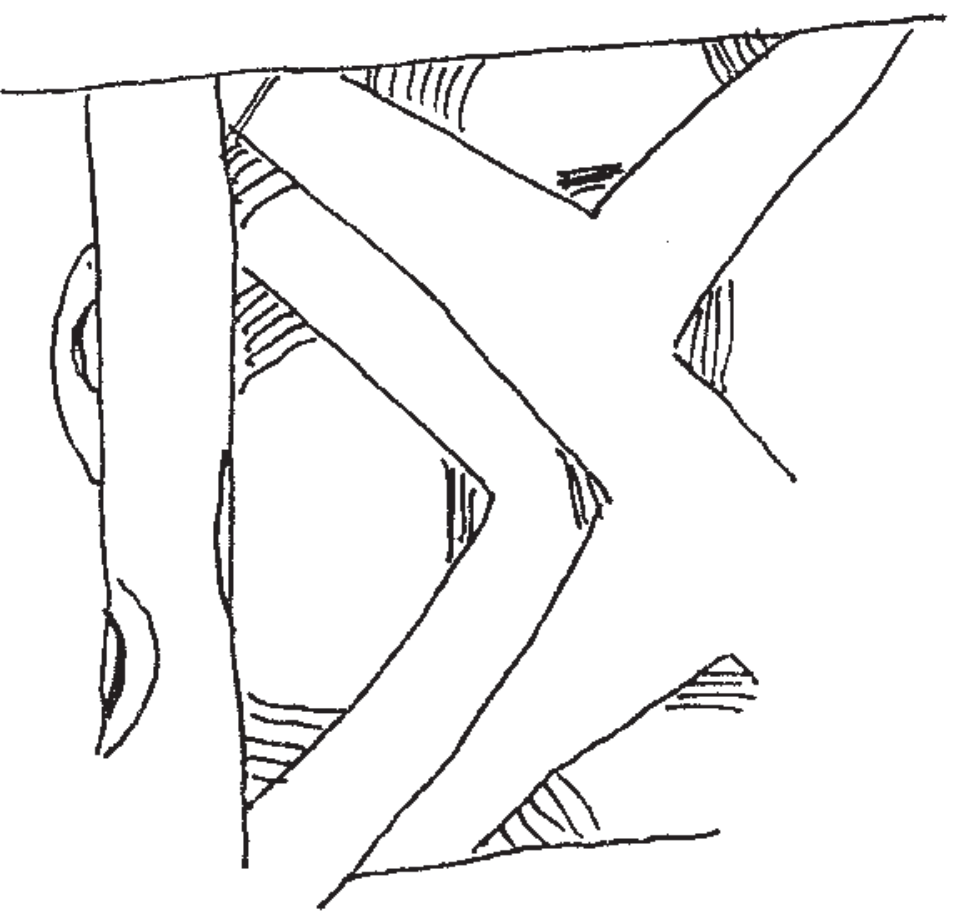

Figure 4. Poynor Engraved rim.

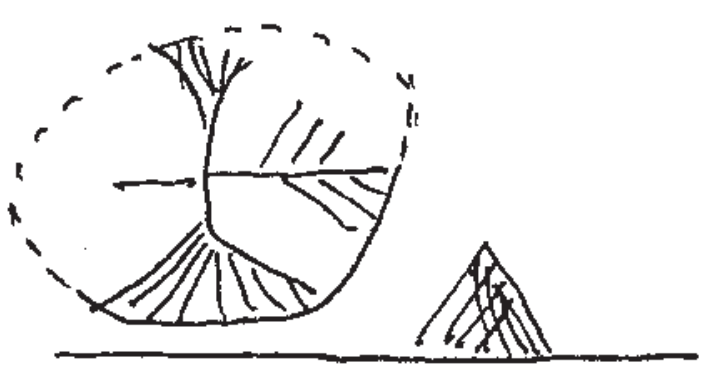

Figure 5. Engraved sherd with cross-arm design. 


\section{Punctated Sherds}

There were nine punctated sherds, including four punctated rims in the Lake Clear ceramic assemblage (Figure 8). Sherd thickness ranged from $6.5 \mathrm{~mm}-10.1 \mathrm{~mm}$ with an average thickness of $8.24 \mathrm{~mm}$, slightly thicker than the overall average sherd thickness of $7.9 \mathrm{~mm}$ (see Table 3). There were four examples of sherds with ovalshaped punctates. Three of the sherds had fingernail/crescent punctates, and one had two rows of fingernail punctates with a small dash through each punctate. One sherd had tear-dropped punctates, while another had large gouge punctates arranged in vertical rows.

Of the four rims, three had flattened lips and one was rounded; three were straight in profile and one was everted. Of the nine punctated sherds found at the site, two had punctates arranged in rows and the rest were randomly placed across vessel rims and bodies.

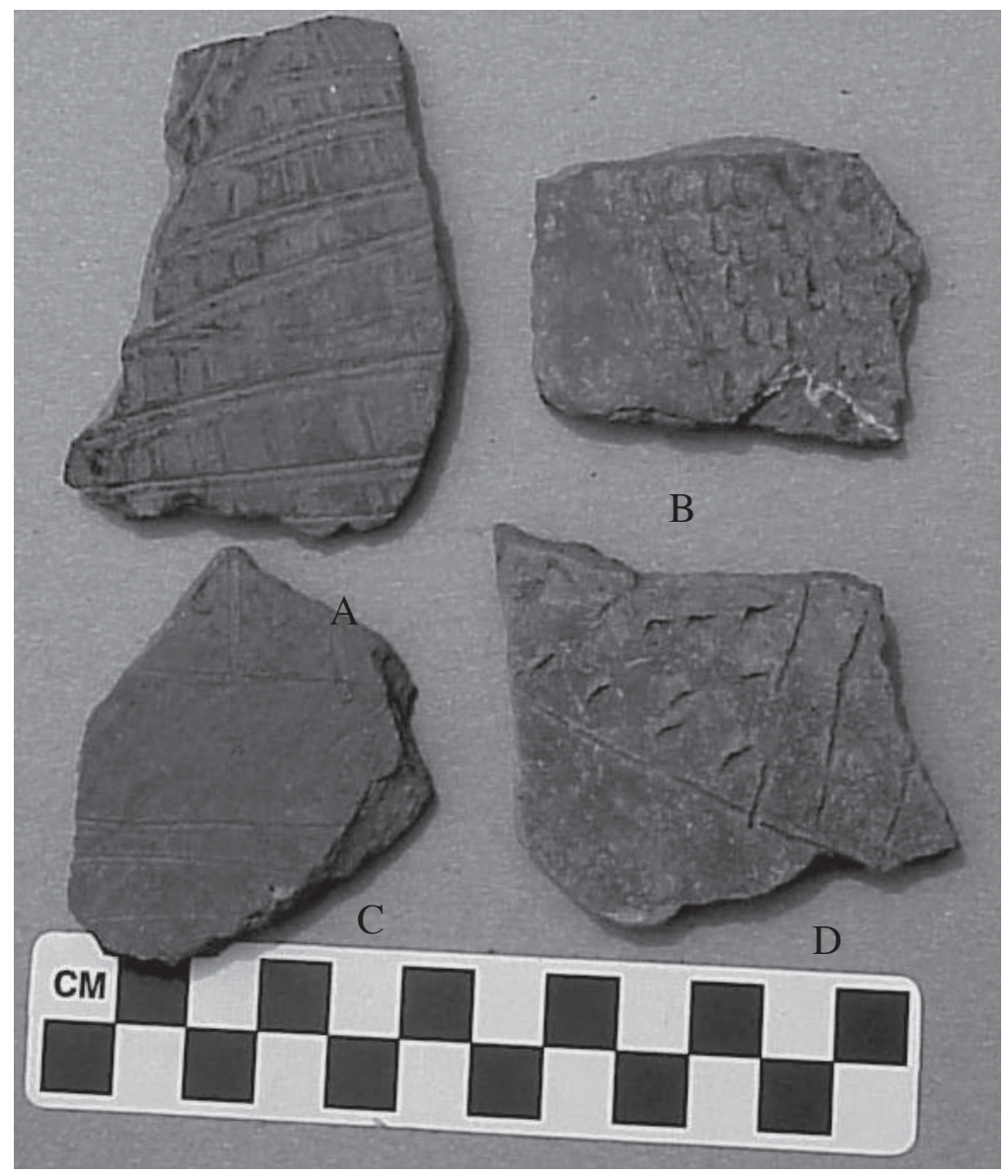

Figure 6. Punctated/incised body sherds. 


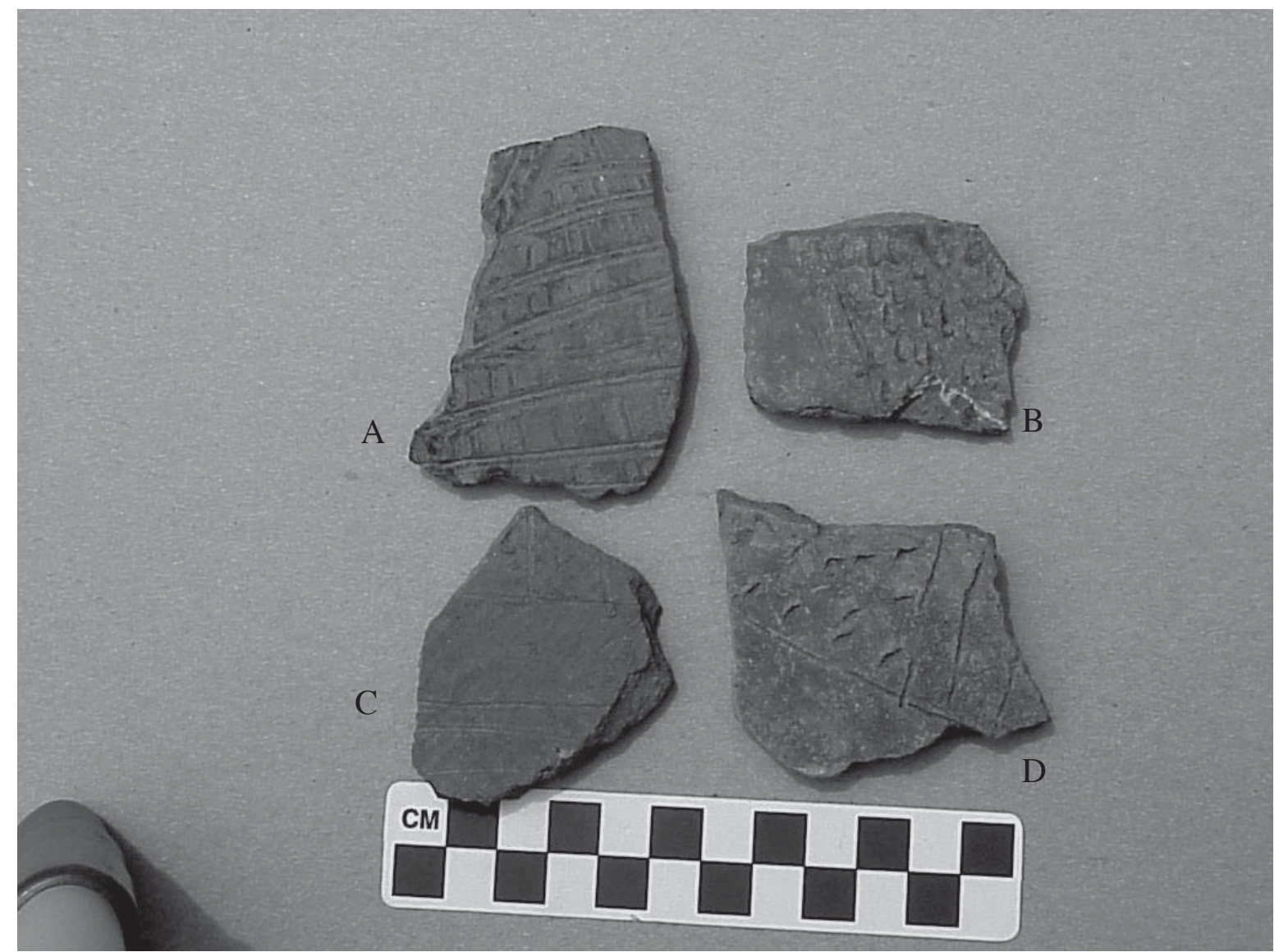

Figure 7. Puncatated/incised sherds.

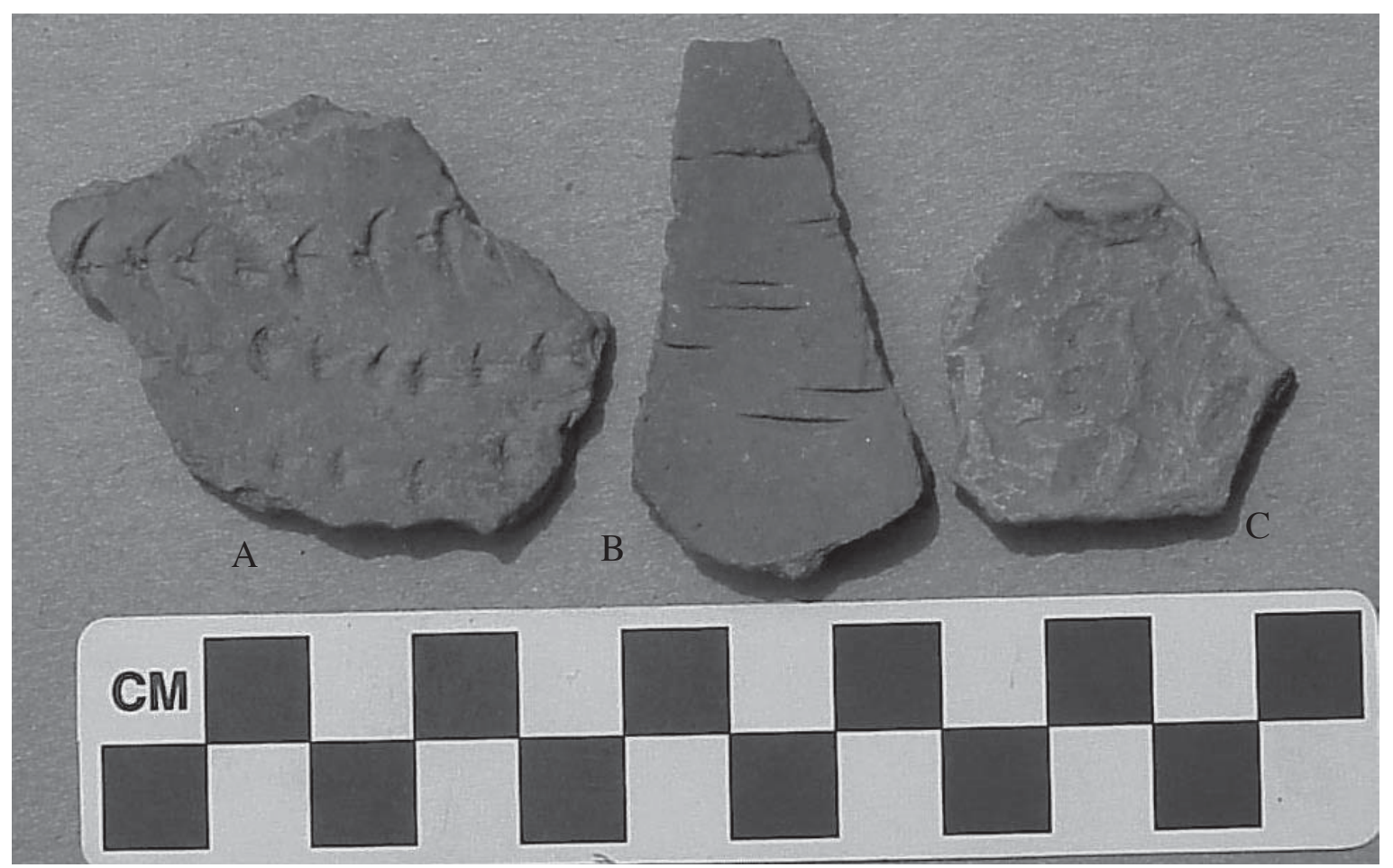

Feature 8. Punctated sherds. 


\section{Brushed/punctated Sherds}

There were five examples of brushed/punctated sherds in the collection, and they range from 8-10.5 mm (average of $9.1 \mathrm{~mm}$ ) in thickness (see Table 4). Two examples had straight or parallel brush marks with large gouge punctates; and another had opposing brush marks with large gouge punctated marks. The fourth example had opposing brush marks with random fingernail punctates. The last brushed-punctated sherd had two rows of tear-dropped punctates separating straight or parallel brush marks.

\section{Pinched/ridged Sherds}

There were two examples of pinched/ridged sherds in the Lake Clear collection. One large sherd (Figure 9) had rows of ridges formed by pushing up the surface with parallel rows of punctates to form a spiral design. The other example had straight ridges formed by deep crescent-shaped punctates on either side of the ridge. Similar examples have been found in the Middle Caddoan period components at the Redwine (41SM193) and Langford (41SM197) sites in Smith County (see Walters 1997; Walters and Haskins 1998), as well as at the Oak Hill Village (Rogers and Perttula 2004) in Rusk County. Evidently this design element has a long history as there is also an example from the Early Caddoan period Boxed Spring site (41UR30) (see Perttula et al. 2000: Figure 18).

\section{Plain Rims}

There were six plain rims included in the Lake Clear collection (see Table 1). Four had rounded lips and one was flattened. The flattened example had a slightly rolled out or flaring lip, and was also thinned and burnished. Four had straight rims and two were everted in profile. One example was everted with a rounded lip and had a large circular lug protruding out from the vessel wall.

\section{Clay figurine}

A clay figurine (5 cm long and $2.8 \mathrm{~cm}$ in diameter) was in the collection (Figure 10). One end was broken and it is not known if it was originally attached to a vessel. The unbroken end had two smoothed, rounded protuberances, one longer than the other. Someone with a better imagination than I can speculate as to what it is represented by the figurine. It was made from a sandy clay paste.

\section{Drilled Base Sherd}

There is one example of a drilled base, or spindle whorl as they are sometimes called. This example, $10.6 \mathrm{~mm}$ thick, was broken through the perforation or dilled hole, and is $11.9 \mathrm{~mm}$ in diameter. Temper was bone/grog inclusions with large quartz grains visible in the paste (Figure 11a). 


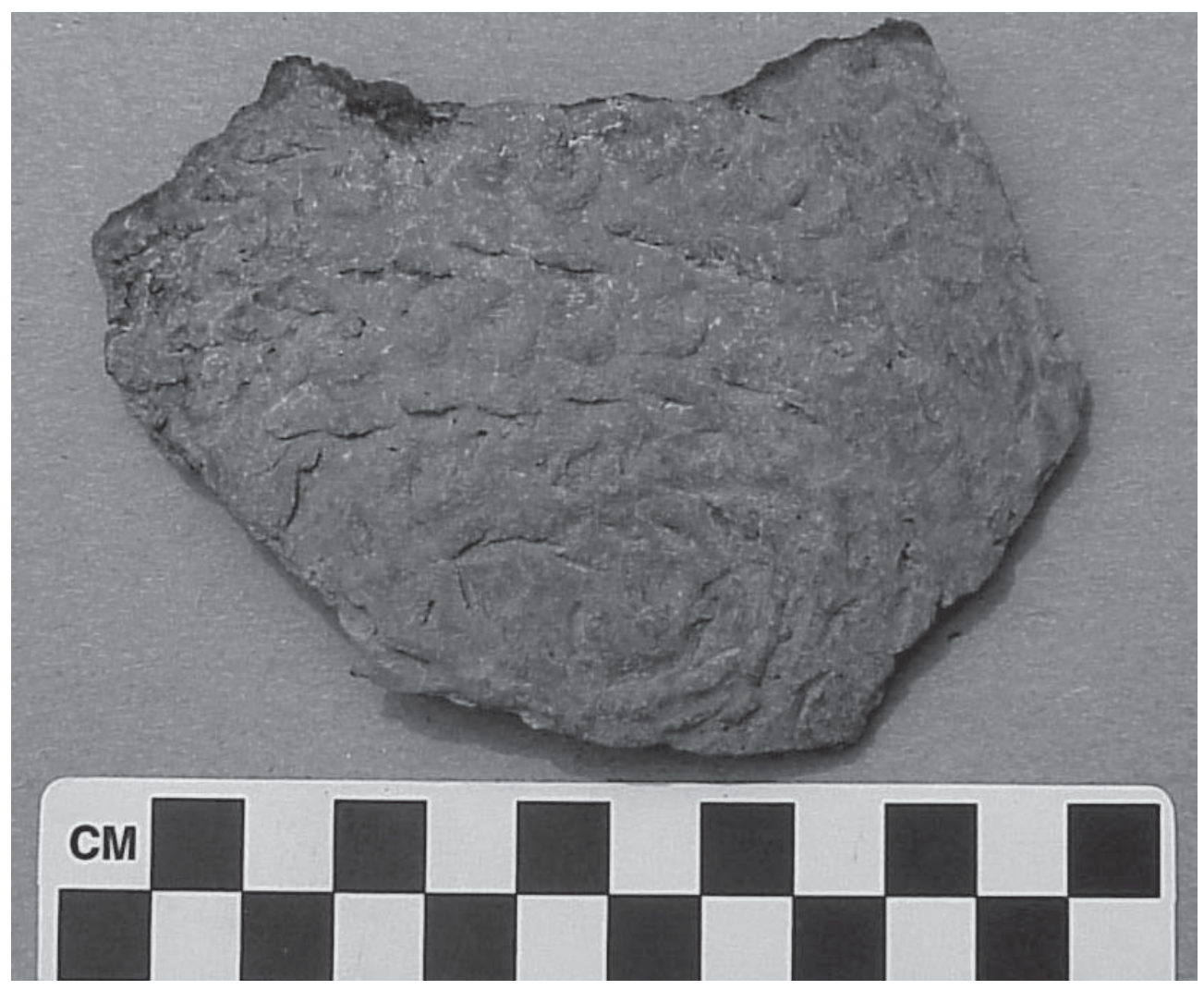

Figure 9 Pinched/ridged body sherd.

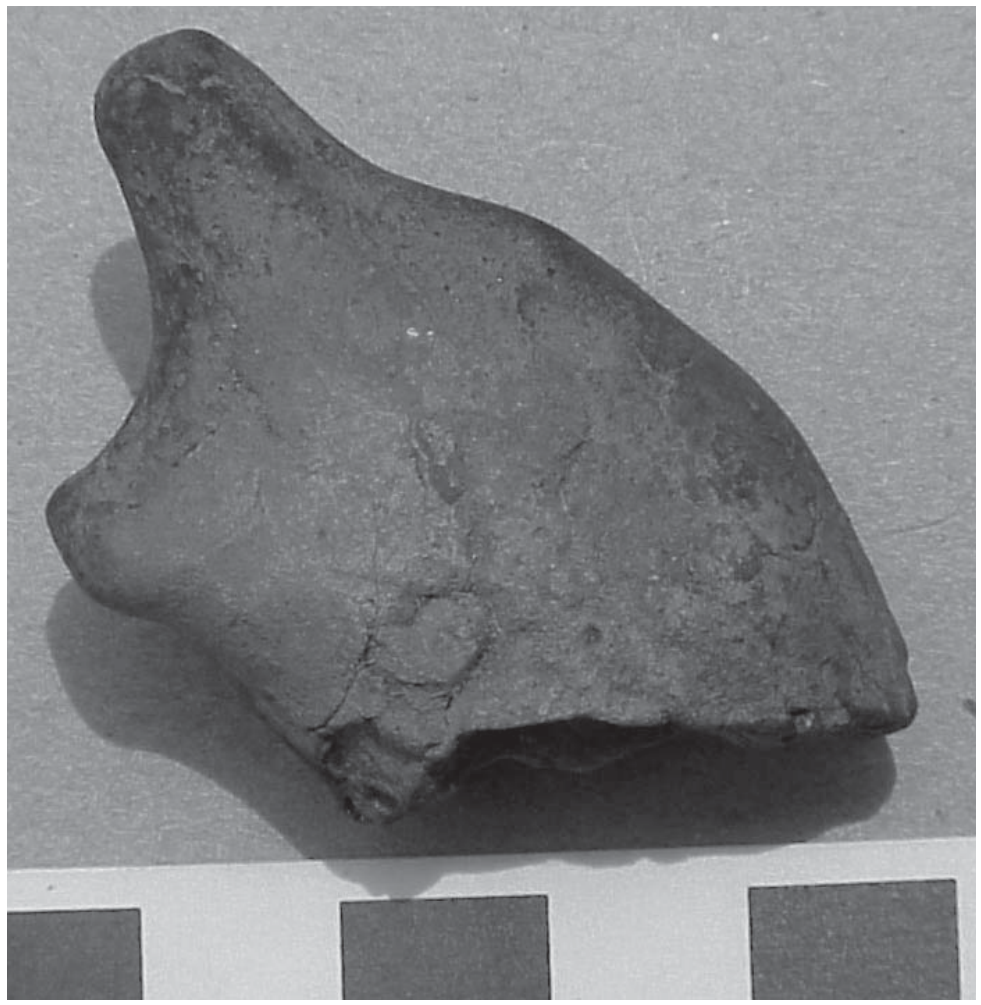

Figure 10. Clay figurine. 


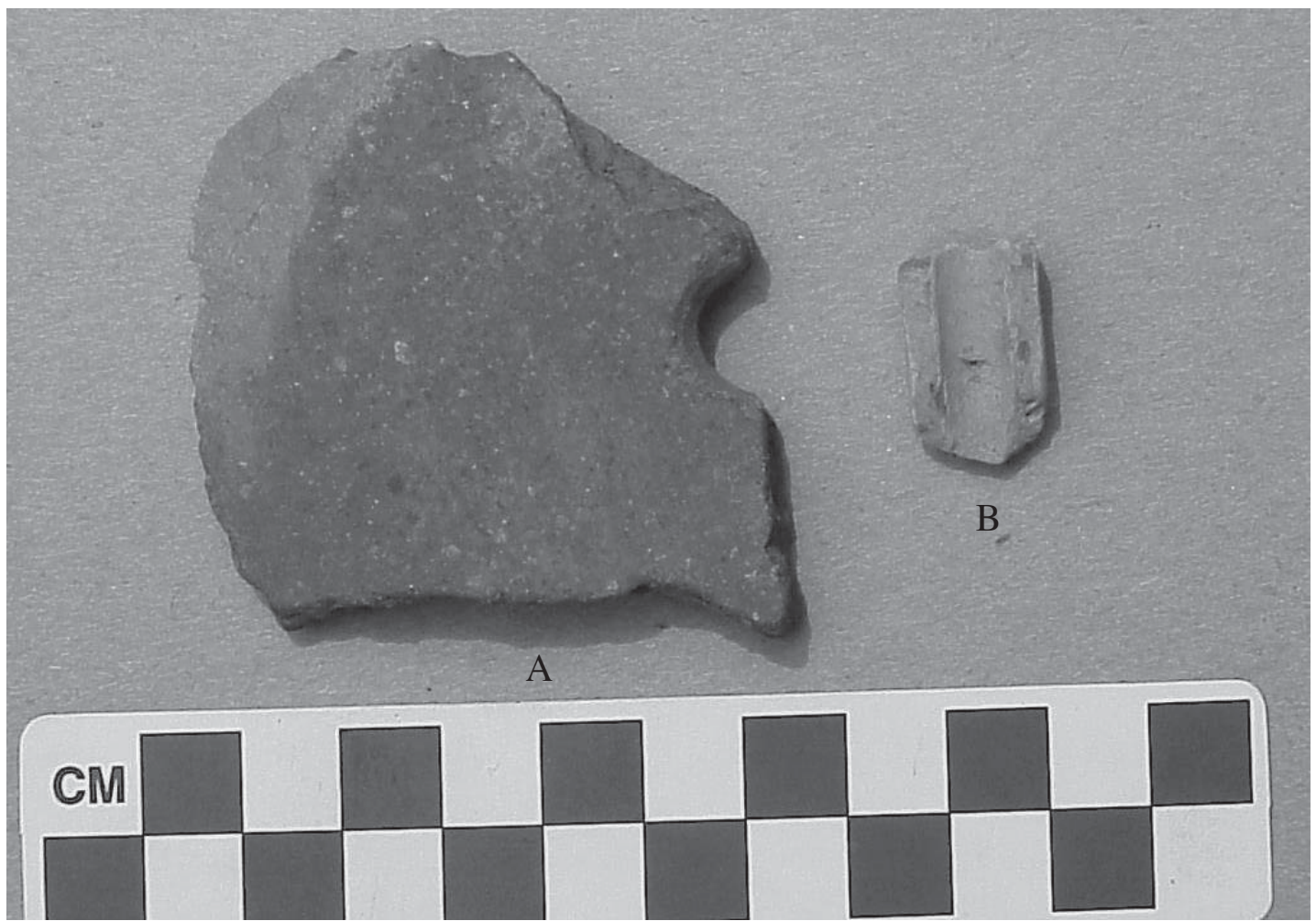

Figure 11. Miscellaneous ceramic objects from the Lake Clear site: a, Drilled base sherd; b, Pipe stem.

\section{Pipe Stem}

A small section, $7.3 \mathrm{~cm}$ long, of a probable Red River variety pipe stem was also found in the Lake Clear site collection. The outer diameter of the stem was $13.7 \mathrm{~mm}$, with a $6.4 \mathrm{~mm}$ diameter hole (see Figure 11b). Red River style pipes (Graves Chapel and Haley varieties) of similar size and thickness were recovered in Middle Caddoan period components at the Oak Hill Village (Rogers and Perttula 2004:Table 77).

Temper was grog with possible vegetative material. A depression on the outside of the pipe stem was first thought to be a punctated decoration but was probably instead a burned-out piece of vegetative material.

\section{Rattlesnake motifs in the Lake Clear Site Collection and other Caddo Sites}

The Canebrake rattlesnake (Crotalus horridus atricaudatus) is a native of East Texas as well as across most of the southeastern United States (Figure 12) It is different enough from the Timber Rattler (Crotalus horridus, crotalus being Latin for "rattle" and horridus is Latin for "dreadful") that it is considered to be a subspecies. (see Dixon 2000) It is also known in the South as the "velvet-tail," because a portion of the body and the tail are velvety black, or "canebrake," because of its preference for the dense canebrakes that covered large portions of the region's floodplains.

The canebrake is a large-bodied snake with adults ranging from 36 to 60 inches in length. The record is 74.5 inches in length. It is distinguished by a reddish-brown stripe running down the center of the back, disrupted by 


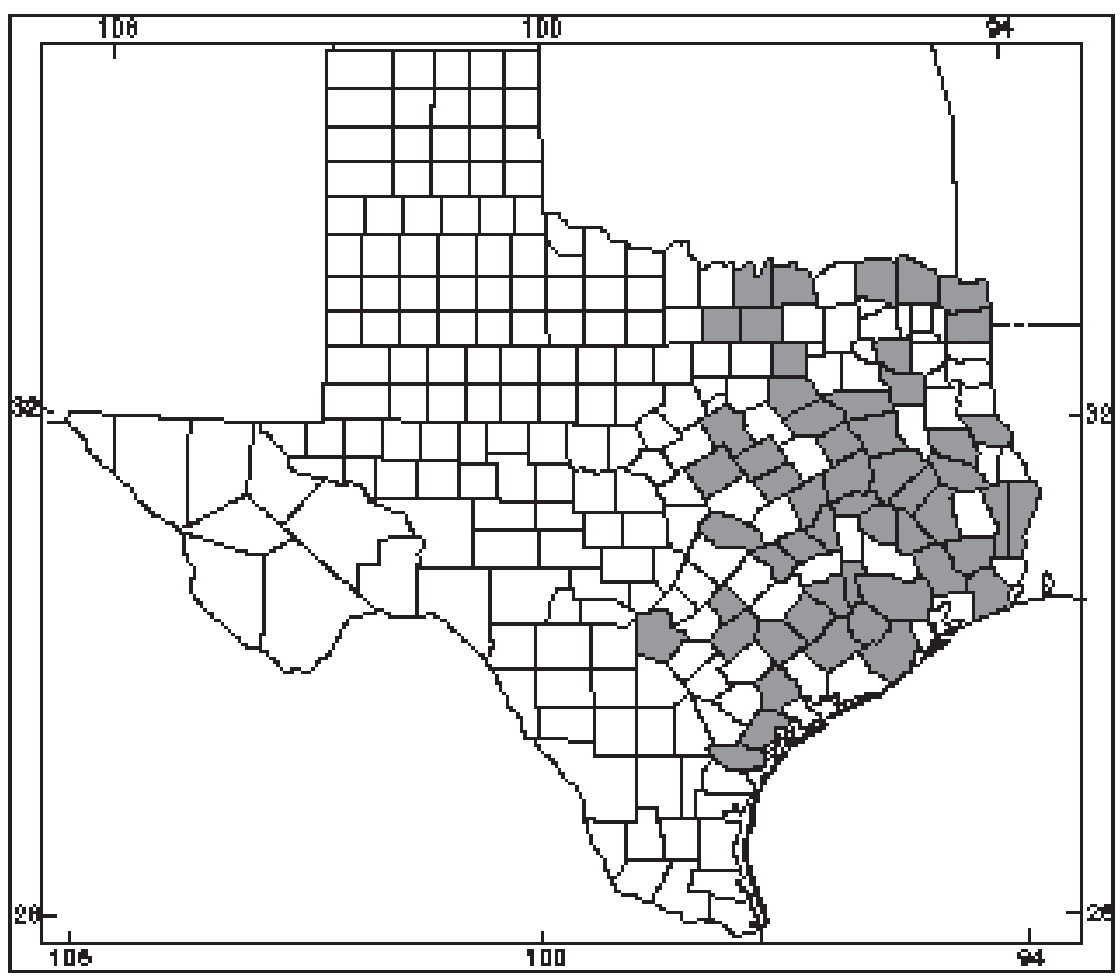

Figure 12. The distribution in Texas of Crotalus horridus atricaudatus, Canebrake Rattlesnake.

a series of large, black, chevron-like cross bands. The head is large and sometimes has a diagonal line through the eye or just behind the eye. Like other pit vipers it has a facial pit, a sense organ that detects heat, located between the nostril and the eye. The canebrake favors densely vegetated riparian habitats. Its early distribution and population size is unknown but at present its numbers are limited and its range is confined to riparian settings in East Texas such as the Sabine River.

My only personal experience with the canebrake rattlesnake was near Longview, Texas, while walking along a dry slough adjacent to the Sabine River. This was in old timber and the ground was clean except for limited amounts of leaf clutter. In my path was a small overturned tree that I could have stepped over but being loaded with fishing poles I veered to walk around. At that point something caught my eye that seemed out of placesomething black and linear - that didn't seem right. As I paused to look closer, I realized what I was looking at: the black tail of a canebrake rattler. Only then was I able to make out the rest of the body camouflaged in the leaves, and he was looking straight at me. Throughout my youth there were tales told about the canebrake or velvet-tail, such as the one about a cousin who while squirrel hunting stepped over a log and onto one's head; or the tale where my daddy and his friends found one in a hollow stump, all in the Sabine River bottoms. Even today this magnificent snake still has the power to awe people.

Snake mythology is the most widespread mythology known to man and can lead down many paths. The Old World basilisk, usually considered a serpent (although it was hard to confirm since anyone who looked at one died), may have been recreated in the New World in the form of the rattlesnake (see Sax 1990). What transferred in the mythology to the New World may have been a cluster of motifs that were identified in the rattlesnake. 
In the Old World as well as the New World, the myth involves a trail of devastation, often even the destruction of vegetation. Tied to this myth is the idea of fascination or charming that gives the snake powers over other animals, and that led to the belief in the "evil eye." I cannot help but inject an idea suggested by Garrison and Arensberg (see Maloney 1976) that the belief in the evil eye is characteristic of cultures that are stratified but not yet bureaucratized; and these beliefs are expressions of envy, often directed across barriers of status and position. In reference to the belief in the evil eye, I am thinking of the forked eye motif found in the Southeastern Ceremonial Complex artifacts in Mississippian sites in the southeastern United States.

Snake motifs are common across the southeastern United States in archeological sites. Seventy-five examples, the most popular animal motif there, occur at the Spiro site in eastern Oklahoma, although all of these are stylized and occur on shell (see Duffield 1964). Similar stylized examples occur on pottery at the Moundville site in Alabama and on Walls-Pecan phase pottery in the lower Mississippi valley, but they are also stylized, often depicting the "feathered serpent" image. These snake motifs are not realistic portrayals like the canebrake rattler motifs present on Caddo ceramics.

Could the rattlesnake motif be a part of a horizon style as defined by Willey and Phillips (1958: 33, 166)? According to Willey and Phillips (1958), a horizon style has "a primary spatial continuity represented by cultural traits and assemblages whose nature and mode of occurrence permit the assumption of a broad and rapid spread." In other words, a ceramic style horizon marker occupies a great deal of space but very little time. Horizon markers are then assumed to be contemporaneous when they occur on different sites, but few sites with snake designs are dated by absolute methods (i.e., radiocarbon dates) so we do not know how rapid was the spread of this motif among northeastern Texas Caddo groups, although its association with other pottery styles would indicate that the origin of the engraved rattlesnake motifs took place in the middle Caddoan time period (ca. A.D. 1200-1400).

I have chosen in this article to limit the discussion of engraved rattlesnake vessels to only those examples that clearly illustrate the rattlesnake motif. Most recordings of engraved rattlesnakes on Caddo sites are limited to single vessel examples - Lake Clear with five different examples, being the exception. It would be interesting to determine if there is a central distribution point for the snake vessels and if they are trade goods when found outside a central distribution area; or given the wide variation in the known examples, perhaps the diffusion of an idea from a central location can be documented in the known archaeological examples. Perhaps an instrumental neutron activation analysis study of a number of engraved rattlesnake sherds could lend some insight to this problem (but see below), but these analyses have yet to be done on a wide-scale across the Caddoan area.

After a long tradition of stylized geometric forms on pottery vessels, why would the Caddo start to depict actual objects on their pottery? Perhaps the snake has been represented all along in the scroll design so common in Caddo pottery (see Hart 1982)?

One study suggests that in times of social or economic upheaval there is an increase in stylistic variability. An increase in the diversity of pottery motifs could also reflect a change that took place in the Middle Caddoan period to the development of stronger regional identities characterized by more localized pottery traditions. Serpent mythology often casts the snake as a symbol of chaos. Hints that this suggestion of chaos and snake mythology are linked is the fact that after the Middle Caddoan period in several parts of East Texas - notably the middle Sabine River basin-- the area is virtually abandoned by Caddo peoples.

The question of what the snake meant to the Caddo can only be inferred through Caddo myths. One example is the myth "Snake-Woman Distributes Seeds" noted by Dorsey (1905:18): 
As Snake-Woman gave each person the seeds she told him that he must plant them, and must care for the plants that grew from them, but must allow no one, especially children, to touch them or even point to them as they grew. She said that until the seeds were ripe they belonged to her, and if any one gathered them too soon she would send a poisonous snake to bite him.

Henri Joutel noted that among the Hasinai Caddo: "women brought in the animals their husbands had killed after they reached the neighborhood of their homes, and they had complete command of the cooking and food supply" (Swanton 1942:163). Joutel also said that “...some one woman in each house had entire supervision of the latter. The fields were cultivated by men and women working together but planting was all done by women, and the heaviest part of farming seems to have fallen upon them" (Swanton 1942:129).

Swanton (1942:225) has written that "if anyone should cut a single cob of corn unless it were preceded by the prayers of the minister, he would be infallibly bitten by a snake." Correspondence with present day Caddo Indian peoples indicate they have no surviving notions about the role of the rattlesnake in Caddo beliefs.

\section{Lake Clear Site rattlesnake motifs on sherds}

There are five sherds - four body sherds and one rim - from the Lake Clear site that depict canebrake rattlesnake designs. The five sherds range from 4.9-6.1 mm in thickness (average $5.4 \mathrm{~mm}$ ), which is a good bit thinner than the average for all the engraved sherds $(6.9 \mathrm{~mm}$ ) (see Table 4$)$. Three of them had bone/grog temper and two had grog temper. All five were fired in a reduced atmosphere and three were subsequently cooled in a low oxygen setting and two in a high or open-air setting. Two of the sherds were from bottles.

The first sherd is made up of three matching sherds from a bottle (Figure 13). Tthere is a horizontal line at the bottom of the vessel that defined the design panel.

There are two snake heads with portions of the bodies and two tails depicted on the bottle sherd. Hatch-marked triangles form a diamond design on the body. This is the only example in the study that clearly show the diamond design rather than the predominant chevron design, and it is possible that they may depict the diamond-back rattler rather than the canebrake. The tails or rattles are $2.5 \mathrm{~cm}$ long on one rattlesnake and $4 \mathrm{~cm}$ long on the other, and they are filled with cross-hatched engraved lines. A rounding of the body segment represents both heads, although one is more blunt than the other. Both heads have eyes drawn as evenly spaced circles (Figure 14). There is red pigment in the engraved lines. Another interesting feature of this Lake Clear sherd is the presence of a faint engraved ladder design that is partially superimposed across one of the snake heads.

The second rattlesnake sherd (Figure 15d) is a rim sherd with an everted rim and flat lip. This sherd is polished on interior and exterior vessel surfaces and is very hard with bone/grog temper. There is a horizontal line at the point where the rim begins flaring out and above the line to the lip are diagonal engraved lines, thicker on alternate ends. Below that line, on the vessel body, are two of what appears to be rattlesnake bodies but no heads are present. There is a portion of what appears to be a rattle similar to that seem on the first engraved rattlesnake sherd.

The third rattlesnake sherd (see Figure 15b) is a grog-tempered body sherd with a design element similar to the second engraved rattlesnake sherd (see Figure 15d), although it is a more stylized. One of the snake bodies is more tightly coiled and has an excised circle in the middle of the design. The fourth sherd (see Figure 15a) has portions of two snake bodies similar to the second and third engraved rattkesnake sherds. There is white pigment in the engraved lines. 


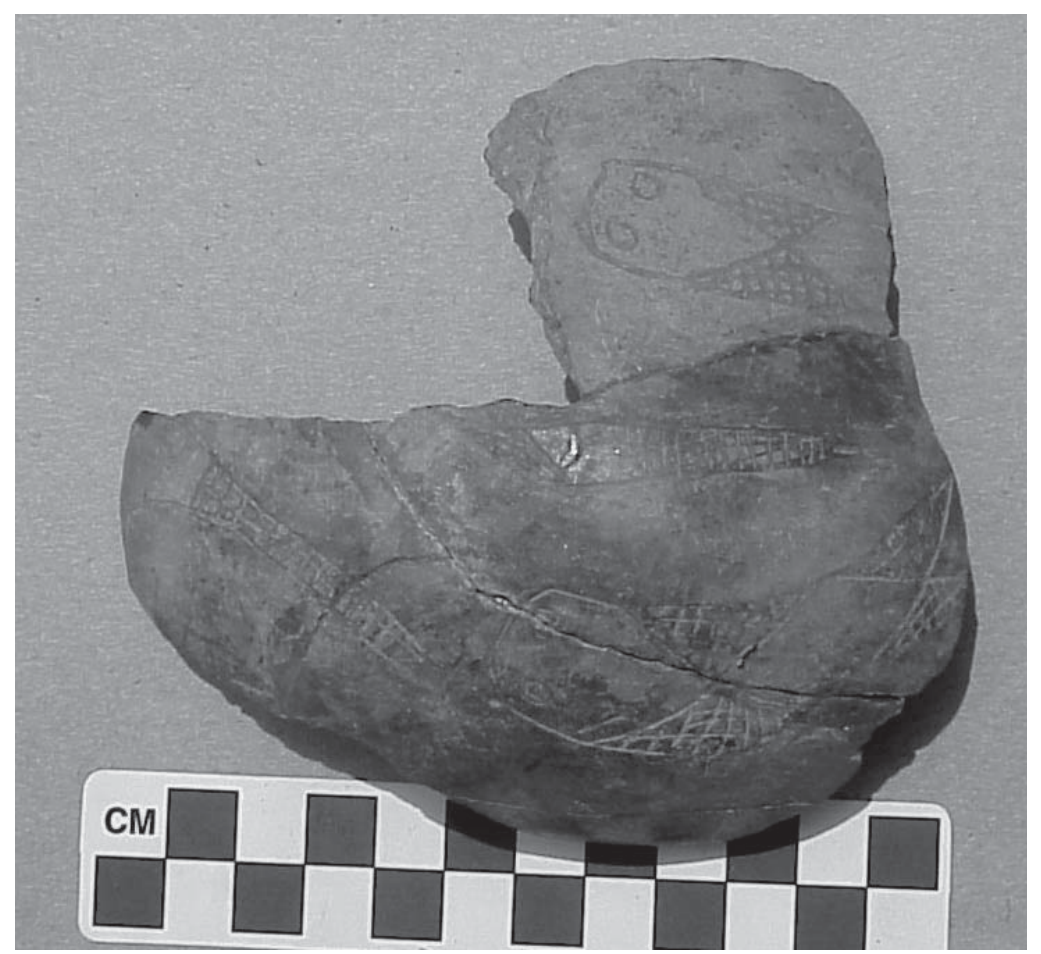

Figure 13. Engraved bottle sherd with Rattlesnake designs.

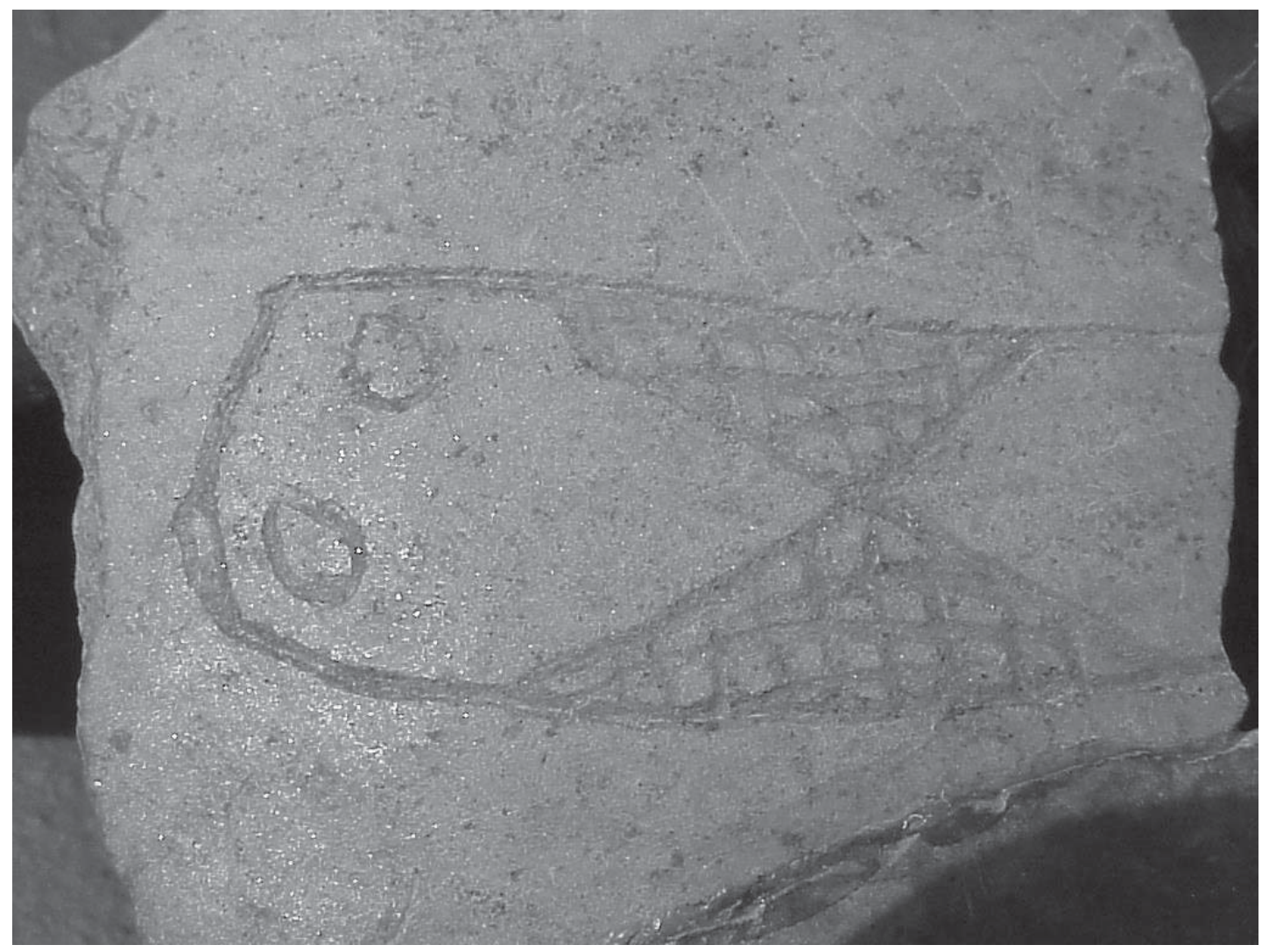

Figure 14. Close-up of Figure 13. 


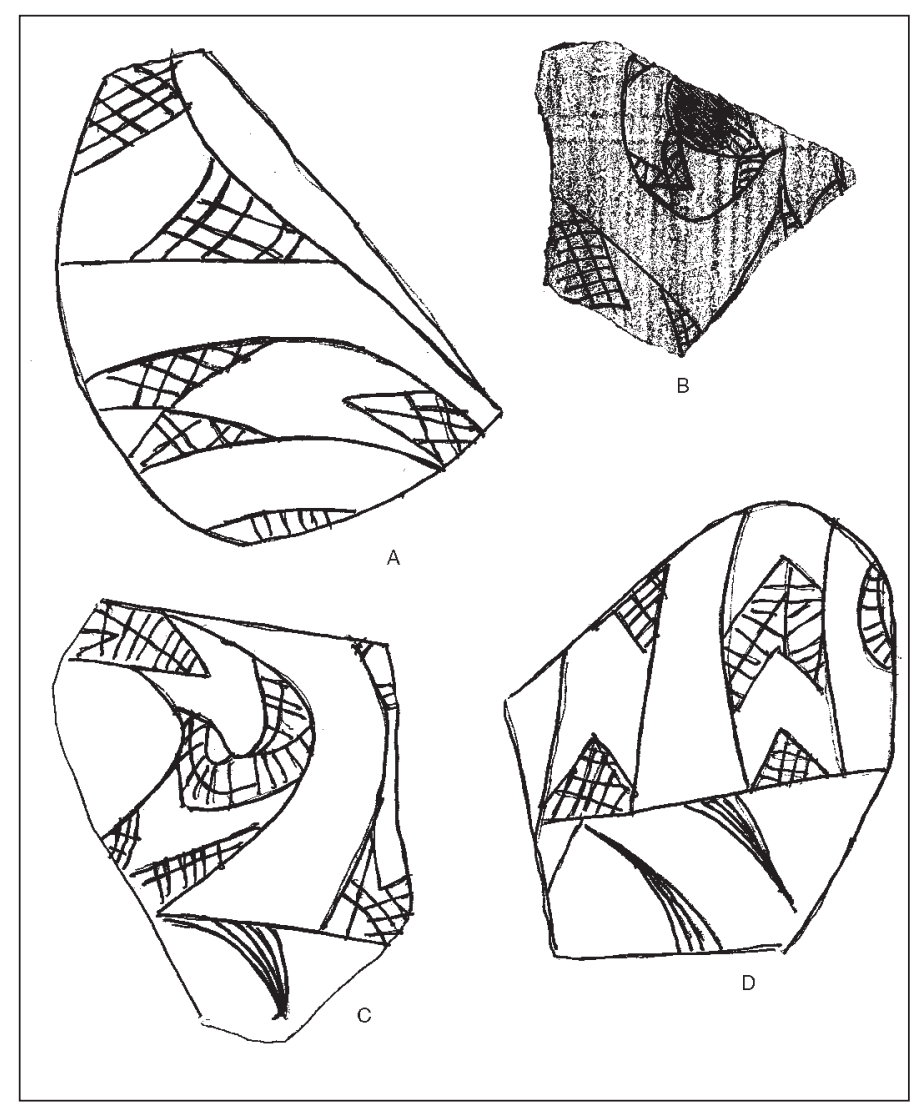

Figure 15. Engraved body sherds with snake designs.

The fifth engraved rattlesnake sherd at the Lake Clear site (see Figure 15c) is from a bottle and has a lower horizontal engraved line defining the design area. A portion of one snake body is depicted along with a crosshatched triangle.

Portions of one of the engraved rattlesnake sherds (INAA Sample No. TKP313) from the Lake Clear site was submitted for instrumental neutron activation analysis (INAA) to the Missouri University Research Reactor (MURR) as part of a mini-NSF Grant (Perttula 1999) with MURR. They were part of a much larger sample of more than 700 sherds from many Caddo sites in Northeast Texas and northwestern Louisiana that have been subjected to INAA.

The INAA was conducted by MURR following standard procedures of sample preparation and data analysis summarized in Neff and Glascock (2000). The determination of chemical compositional groups for the Caddo sample as a whole is based on a data base of more than 700 samples from northeastern Texas and northwestern Louisiana obtained from Early (A.D. 10001200), Middle (A.D. 1200-1400), and Late Caddo (A.D. 1400-1680) sites, as well as a few Woodland (ca. 200 B.C.-A.D. 800), Formative Caddo (ca. A.D. 800-1000), and historic Caddo (post-A.D. 1680) sherds.

The INAA results indicate that the Lake Clear engraved rattlesnake sherd can be assigned to the Rusk chemical group. Mahalanobis distances from the centroids of the three largest chemical groups-Titus, Red River, and Rusk-indicate that this particular sherd exceeds the $1 \%$ probability level for membership in the Rusk chemical group: $\begin{array}{lllll}\begin{array}{l}\text { Sherd } \\ \text { sample no. }\end{array} & \text { Site } & \text { Titus } & \text { Red River } & \text { Rusk }\end{array}$

$\begin{array}{lllll}\text { TKP } 313 & \text { Lake Clear } & 0.000 & 0.000 & 5.785\end{array}$

The Rusk chemical group of clays is currently known almost exclusively from Early to Late Caddoan period ceramics from sites found on the south side of the Sabine River, but in the middle reaches of the Sabine River basin, including Oak Hill Village (41RK214), as well as in numerous sites in the Angelina River and Attoyac Bayou basins. About 53\% of the INAA sherds from Oak Hill Village are assigned to the Rusk group, with the other 47\% assigned to the Titus group (Rogers and Perttula 2004). The Rusk chemical groups sherd from the Lake Clear site appears to have been from a locally manufactured vessel using local clays. 


\section{Known Examples of Canebrake Rattler Motifs at Other Caddo Sites}

Archeological sites were created in a regional context. Using the canebrake rattlesnake motif to better understand this context we can: (1) determine the distribution of the snake motif both in time and space and (2) use the snake motif to explore interaction between different Caddo groups and regions.

Of the 14 examples discussed in this article, eight are from the Big Cypress Creek drainage, three are from the Sabine River basin (all on the south side), two are from sites in the Red River basin, and one is from a site in the Angelina River basin. Figure 16 shows the overall area of known examples, with two smaller areas or clusters showing the main concentrations. There seems to be no stylistic similarities of the engraved rattlesnakes either within individual drainages or between them. Also, there are two bottles from two different sites that are almost identical, except for how the tail/rattle is depicted, that are from opposite ends of the distribution area, namely the Red River and the Angelina river basins. Perhaps this indicates that the idea of the snake spread through the region and individual groups made their own determination of how the snake was to be illustrated. Based on the few sites with dates and associated artifacts, the snake motif seems to have originated in a particular time period, the Middle Caddoan period (ca. A.D. 1200-1400), and continued to be made and used in the Late Caddoan period in Titus phase sites in the Big Cypress Creek basin. Whether there were changes in the engraved rattlesnake design through this period of time is difficult to determine because of the lack of dates from most of these sites.

In summary, (1) most of the engraved rattlesnake motif examples on pottery vessels came from a concentrated area in the Big Cypress Creek drainage in northeastern Texas; (2) most were on bottles; (3) the majority of the examples were on vessels from burials; (4) there were very limited numbers of specimens from each site; (5) the known examples fall in the Middle and Late Caddoan periods; but apparently originated in the Middle Caddoan period, and (6) each site seemed to have had its own interpretation of what the rattlesnake should look like or how it should be depicted. In most instances the engraved decoration was a realistic representation of the canebrake rattlesnake.

\section{Discussion of known sites}

In an effort to look for stylistic similarities, the known examples are discussed by drainages and when possible by when they appear to date in local Caddo chronological sequences. Briefly, I will describe each example, the kind of site and available dates, presence of mounds, structures, cemeteries, and the context in which the engraved rattlesnake example was from at the site.

\section{Sabine River Drainage}

In the Sabine River drainage one of the better-dated sites is the Oak Hill Village (41RK214) (see Rogers and Perttula 2004) a large habitation site on a tributary of the Sabine River that has been dated to ca. AD 1150-1400. The snake example came from the southern part of the habitation area, Area A (Figure 17). This area was used by Caddo peoples as a residential area through all parts of the village occupation.

Lake Clear (41SM243) has not been dated by radiocarbon dating, but it has decorated ceramics - including engraved ladders, scrolls, and starbursts - and an example of a Red River long-stemmed pipe that indicate that 


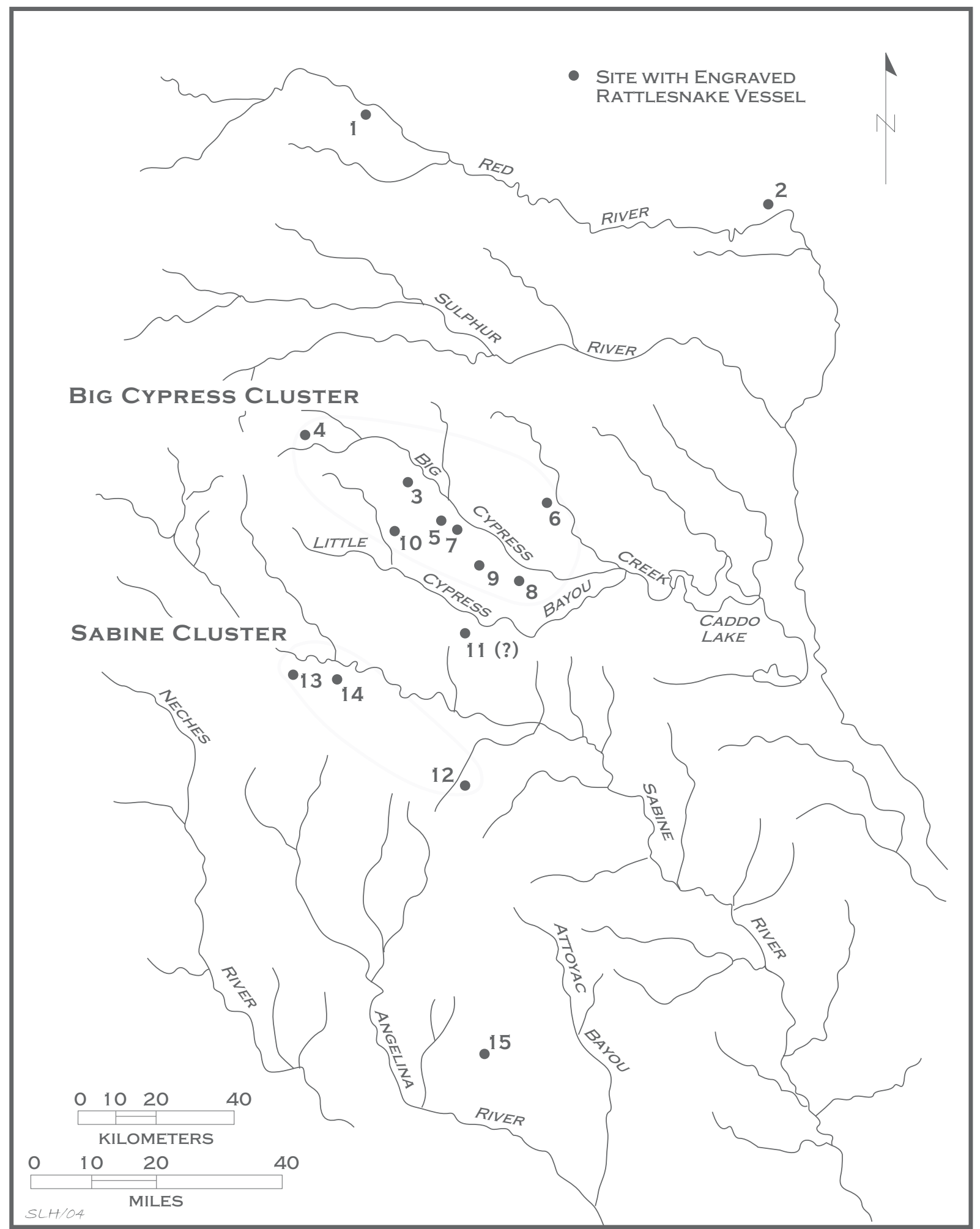

Figure 16. Distribution map of known rattlesnake motif examples: 1. Holdeman (41RR11); 2., Miller County, Arkansas (Museum of the Red River); 3., Harold Williams (41CP10); 4., Benson's Crossing (41TT110); 5., Graydon Adkins (41UR21); 6., Avinger Rest Stop (41CS132); 7., Shelby (41CP71); 8., Pine Grove (41HS826); 9., Henderson-Southall (41UR3); $10 .$, D. Head; 11., Kennedy Collection; 12., Oak Hill Village (41RK214); 13., Lake Clear (41RK243); 14., Langford (41SM197); 15., Washington Square Mound (41NA49). 


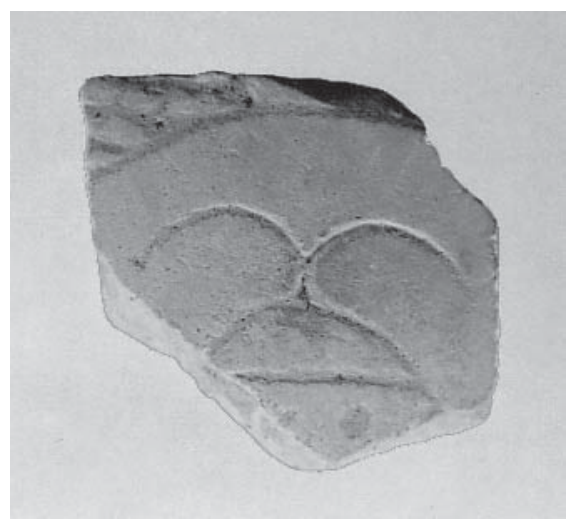

Figure 17. Engraved rattlesnake example from the Oak Hill Village site (41RK214).

its occupation falls somewhere in the Middle Caddoan period. Since there were no whole vessels the rattlesnake sherds are assumed to be from the habitation area.

The Langford site (41SM197) has also not been dated but decorated styles in the ceramics include engraved ladders, circles, and a variant of Foster-Trailed Incised, all which have been associated with the Middle Caddoan period (see Walters 1997). The snake example was on a beaker from a burial (Figure 18).

\section{Big Cypress Creek Drainage}

The Pine Grove site (41HS826), not dated, had ceramics that indicate a Late Caddoan Titus Phase occupation (ca. A.D. 1430-1680). The ceramics found there include Ripley Engraved, Harleton Appliquéd, and Belcher Ridged. There were two examples of engraved rattlesnakes at this site, one a cut-down bottle with snakes circling the vessel (Figure 19a-b) and another example from a carinated bowl that only depicted the tails and rattles (Figure 20). Both examples were from burials in a small cemetery that was separate from the habitation area, as is common on Titus phase sites.

The Avinger Rest Stop site (41CS132) is located on the Black Cypress drainage. It has not been dated by radiocarbon analysis, but is thought to date to the Middle Caddoan period according to Nelson and Turner (1997). This example was on a bottle found in a burial (Figure $21 \mathrm{a}-\mathrm{b}$ ).

The Harold Williams site (41CP10) is located on Dry Creek, a tributary of Big Cypress Creek. It was the location of the 1967 Texas Archeological Society Field School. (see Turner et al. 2003). Radiocarbon and Oxidizable Carbon Ratio dates from work done at the site in 2000 suggest the Middle Caddoan period component at the site dates from A.D. 1191-1372 (see Turner et al. 2003: 22-26). The snake example was from a bottle from a Middle Caddo burial (Figure 22).

The Shelby Site (41CP71), formally known as the Tracy site, is a major Titus phase settlement and community center on Greasy Creek; this is also a tributary of Big Cypress Creek. Available radiocarbon dates from the mound range at 2 sigma from AD 1255-1650 (Perttula and Nelson 2004: Table 1), while four radiocarbon dates from the village range also from AD 1255-1650 (at 2 sigma) (Perttula and Nelson 2004:Table 4). OCR dates in the village suggest that the occupation took place between ca. A.D. 1436-1506.

In addition to a small mound, and a substantial habitation area, a large number of Titus Phase burials have been dug there over the years, and they have yielded Ripley Engraved, Taylor Engraved, Hodges Engraved, and Bailey Engraved wares in addition to Harleton Appliquéd (see Thurmond 1990; Perttula and Nelson 2004). There are reports of mid- to late 17th century archaeological deposits on the site. It is unknown what the context of the engraved rattlesnake pot was at the Shelby site (Mitchell 2000), although it is likely from a burial. This example consisted of engraved snakes on a bottle.

The Henderson-Southall Site (41UR3) in the Lake O' the Pines area was recorded by A.T. Jackson in 1931. No radiocarbon dates are available from the site. Later testing indicated a Titus phase component with Ripley 


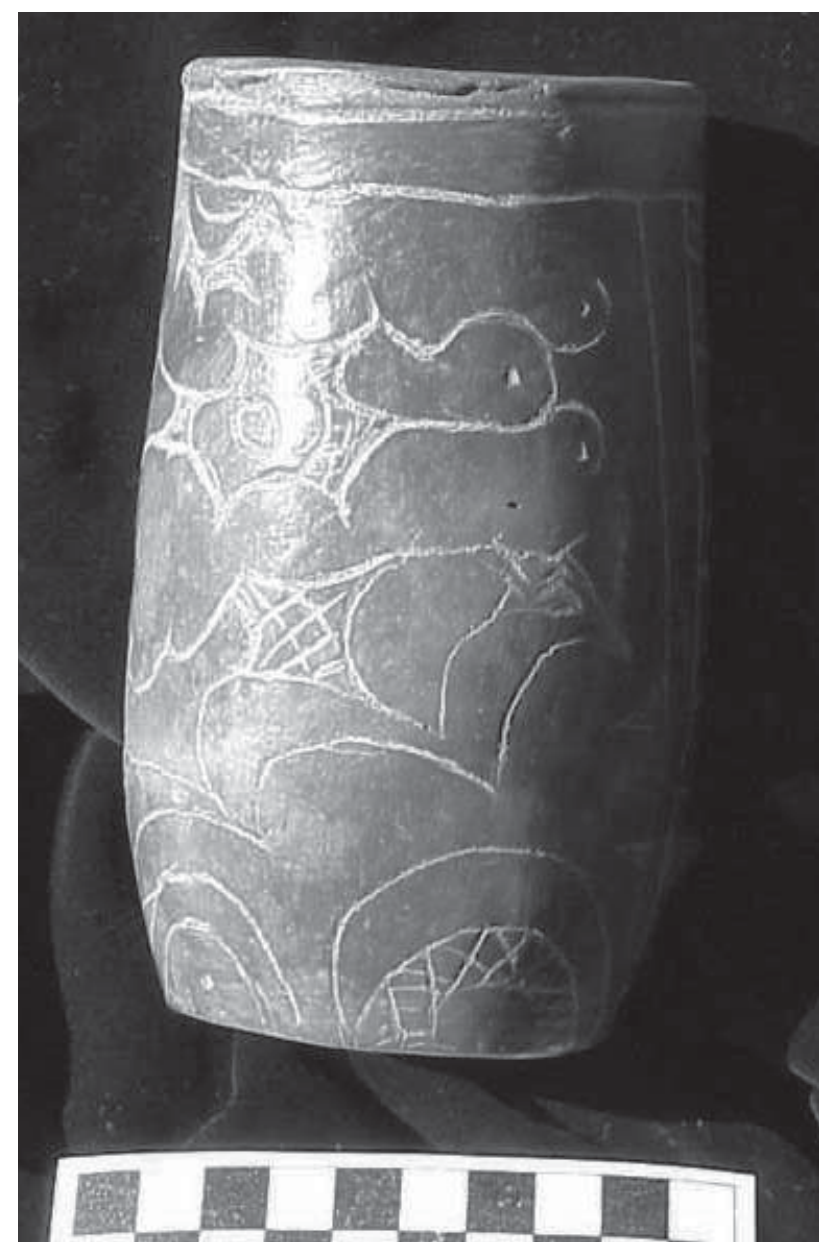

Figure 18. Langford Site (41SM197) engraved rattlesnake beaker.
Engraved, Keno Trailed, and examples of brushed, pinched, and incised utility wares (see Thurmond 1990:203-204). Many Titus phase burials have been excavated here in more recent years This engraved rattlesnake example was from a bottle (Figure 23).

The Benson's Crossing (41TT110) site was the location of the 1978 University of Texas Field school. Described by Thurmond (1990:196-200) as a Titus phase occupation with Ripley Engraved and Avery Engraved, others (see Nelson and Turner 1997) believe that the ceramics from the site are more consistent with a Middle Caddoan period occupation, and that the supposed Titus phase ceramics are really an earlier stylistic manifestation. From the Field school collection there was a crudely executed and highly stylized feathered serpent motif on a red-slipped bowl sherd.

The D Head Site (site number pending) is located on a small tributary of Big Cypress Creek. There was one example of a rattlesnake head and portion of the body from a bottle that has red pigment in the lines (Figure 24). There may be a portion of a rattle shown and there are other triangular crosshatched elements that may be filler zones between the snake designs. The eyes of the snake are drawn as semi-circles on each side of the head with small dots for the eyes. In addition, there are two small dots toward the back of the head. At the mouth end of the head there are two small-etched $5 \mathrm{~mm}$ long lines that may represent fangs.

A small collection of 25 decorated sherds from this site indicate a Middle Caddo occupation. In addition to the engraved snake sherd there were seven brushed sherds, five punctated sherds, including one rim (four had punctates in rows and three had random punctates), three Pease Brushed Incised sherds with vertical appliqued fillets and brushing in between, two pinched-ridged sherds, two brushed/punctated sherds, and five other engraved sherds, including one rim. The engraved examples include two with pendant triangles, one with a circle and cross design, and one with crude cross-hatching. There were reports of burials from this site but no other information is available.

The Graydon Adkins site (41UR21) had a bowl with engraved snakes. According to Robert L. Turner (1997), this example, which he describes as "eared" and also as a compound bowl, was from a Middle Caddoan period cemetery in the Big Cypress Creek valley. While the body and tail of these snakes are similar to other examples, the heads are very stylized, completely unlike any other known examples (Figure 25).

There is one example from the Carson Kennedy collection. It is from an unknown location in the Big Cypress Creek basin, although the bulk of this collection was from Upshur County, Texas. It was hastily drawn some 

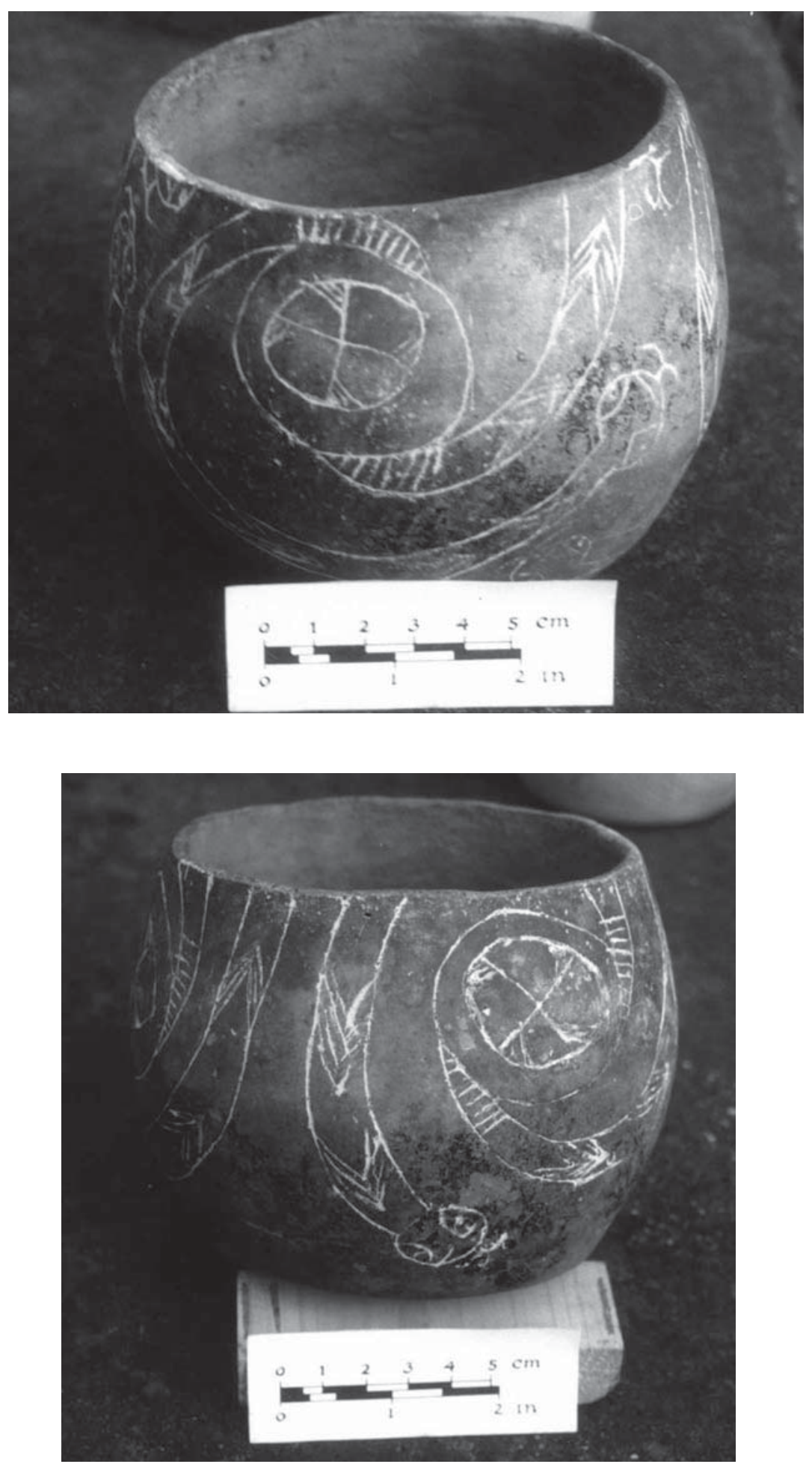

Figures 19. Two views of the engraved bottle from the Pine Grove site (41HS826). 


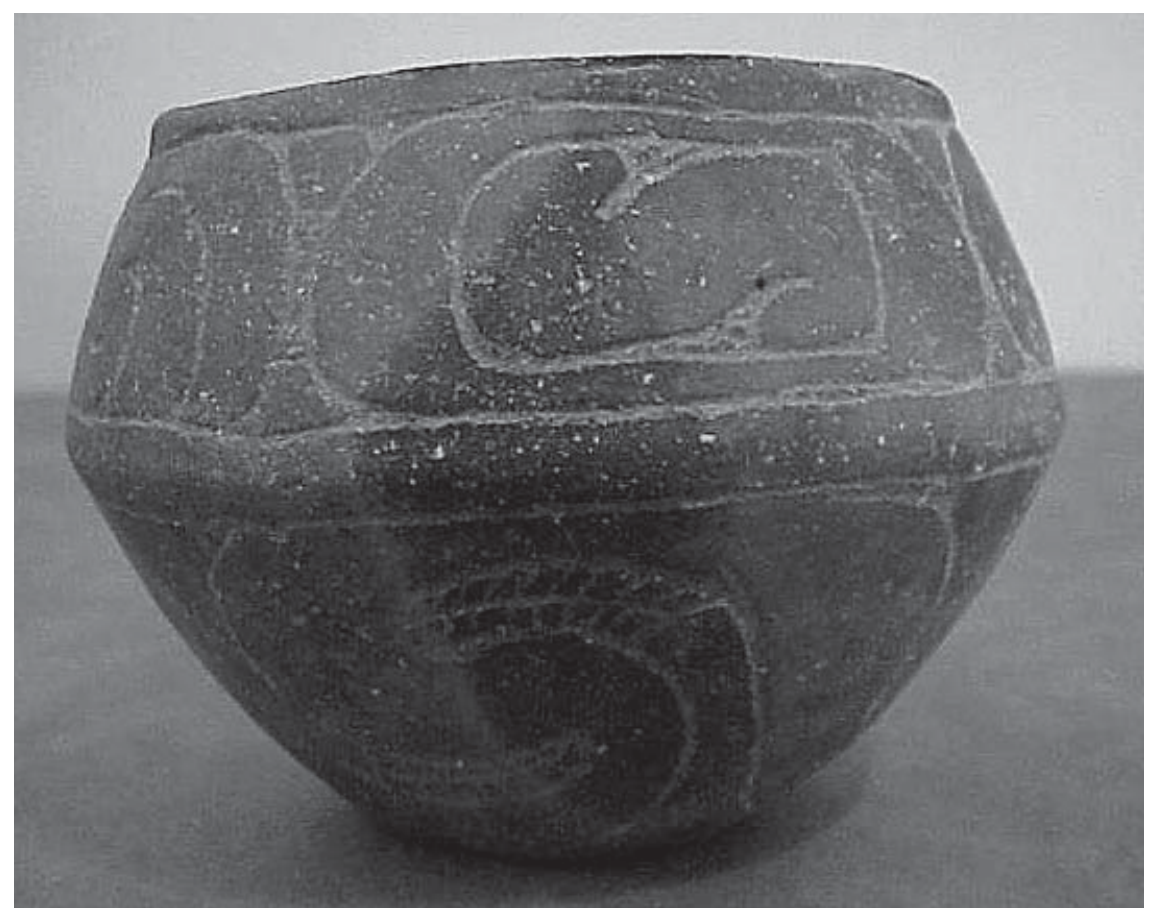

Figure 20. Engraved carinated bowl, from the Pine Grove site (41HS826).

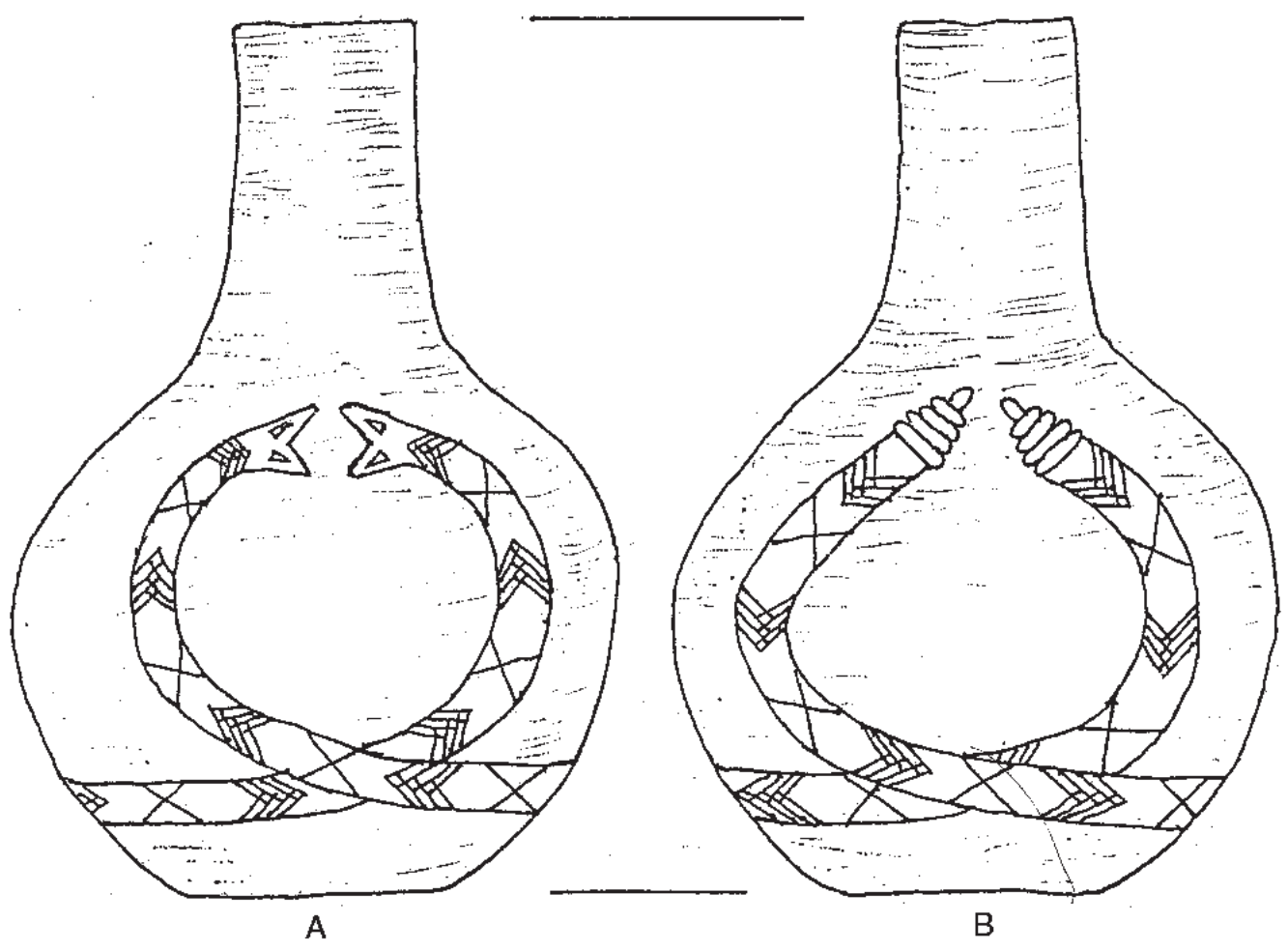

Figures 21. Vessel drawings of an engraved bottle from the Avinger Rest Stop site (41CS132), from Nelson and Turner (1997). 

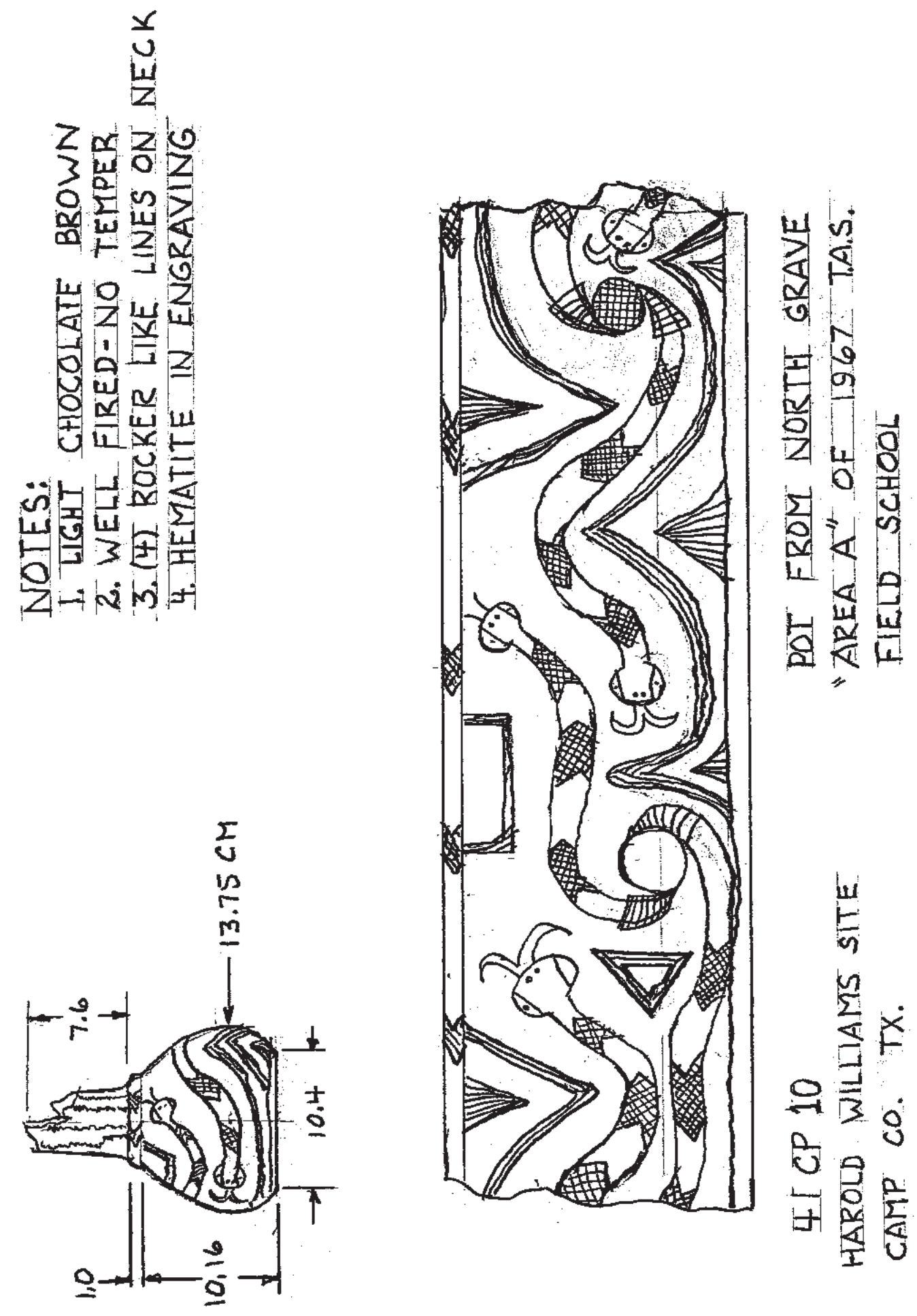

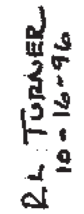
3 แ. a w $=0^{-1}$ 0 1 2 $8 \mathrm{~N} \mathrm{v}$ 7) int $40=$

以ु난 田3田

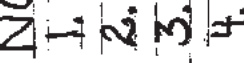
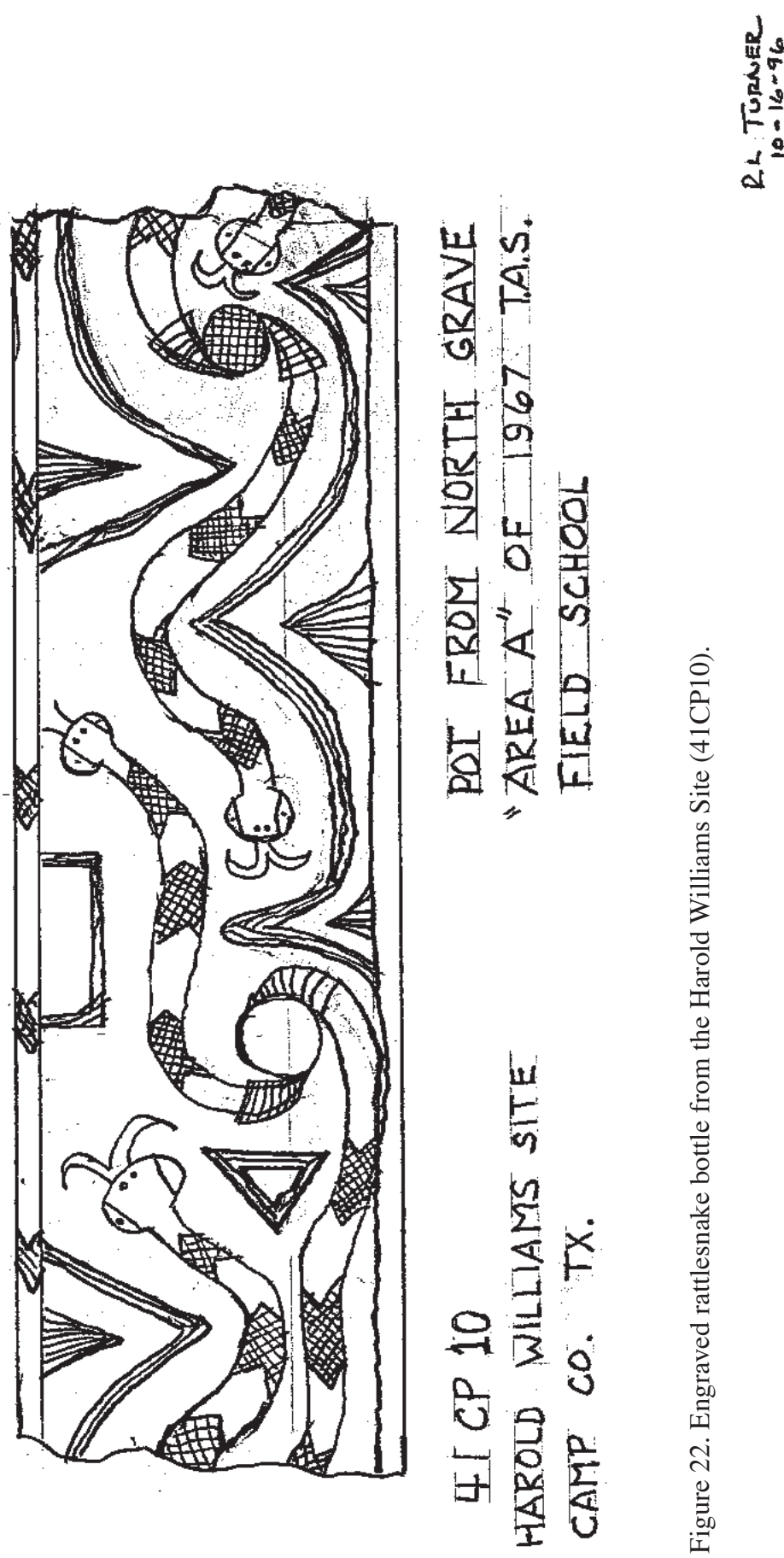


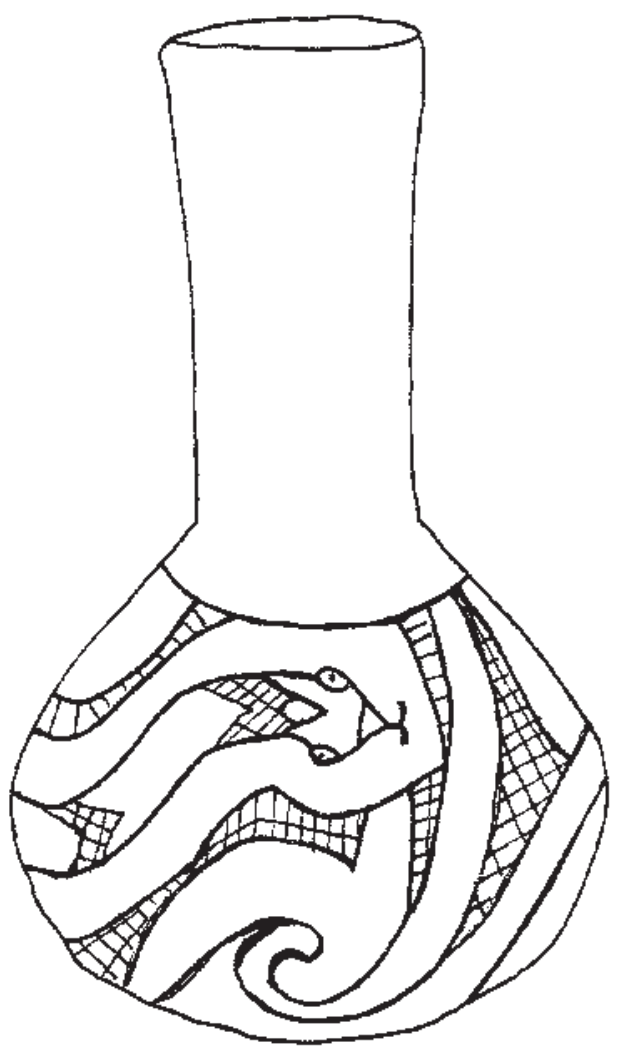

Figure 23. Henderson-Southall site (41UR3) engraved rattlesnake bottle years ago, with not a lot of attention to detail other than it was an engraved rattlesnake vessel. Unfortunately this collection has been sold and is no longer available for study.

\section{Angelina River Drainage}

In the Angelina River drainage in East Texas, extensive investigations at the Washington Square Mound (41NA49) (see Hart 1982; Corbin and Hart 1998) place that occupation at A.D.1268-1302 on the basis of the averaging of several calibrated radiocarbon dates. There was one bottle from a shaft burial with engraved snakes (Figure 26). Except for the rattles, this bottle is almost identical to the example from the Museum of the Red River that was reported to be from Miller County, Arkansas (see below). This vessel was included in the tentative Nacogdoches Engraved type by Hart (1982), but the key attributes for the type are apparently the fill elements and not the actual snake motif.

\section{Red River Drainage}

The engraved rattlesnake vessel example from the Museum of the Red River, according to personnel from the museum, was from Miller County, in southwestern Arkansas (Figure 27). No radiocarbon dates or associated pottery examples are

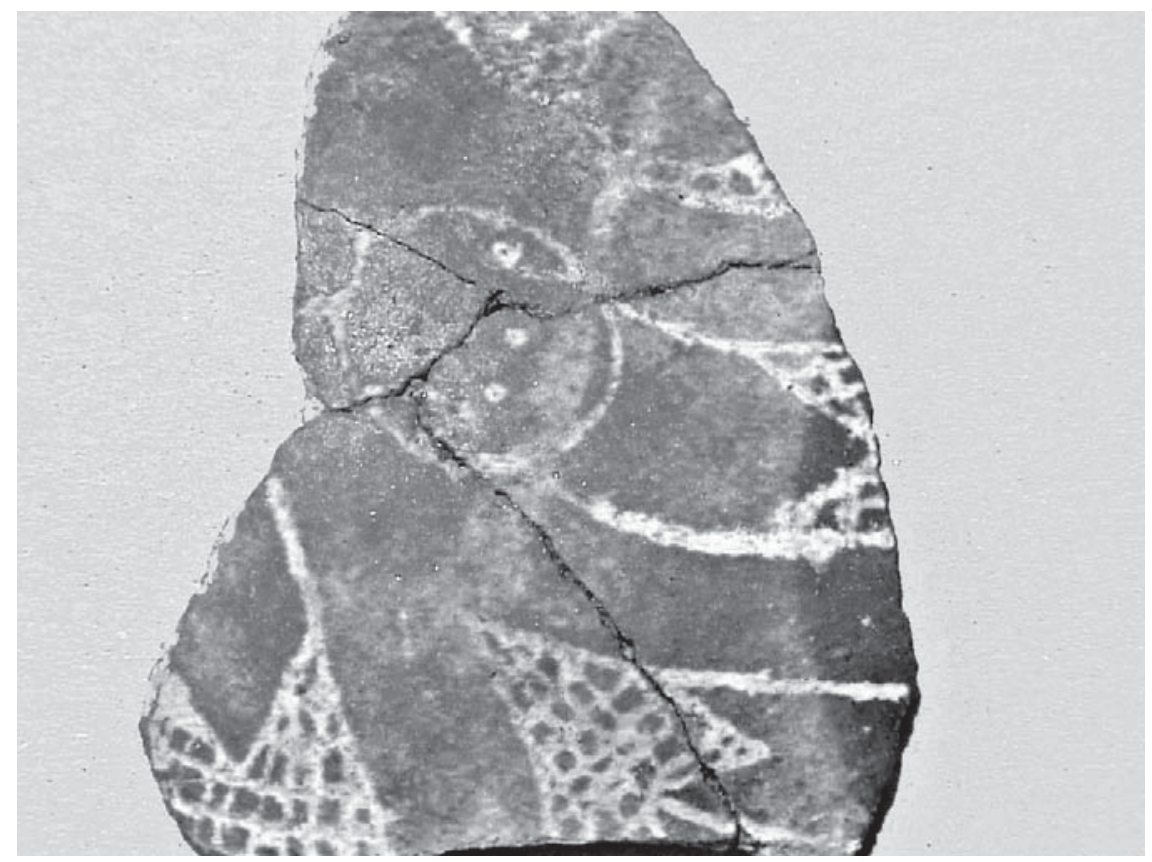

Figure 24. Engraved body sherd from the D Head site with rattlesnake head and red pigment. 


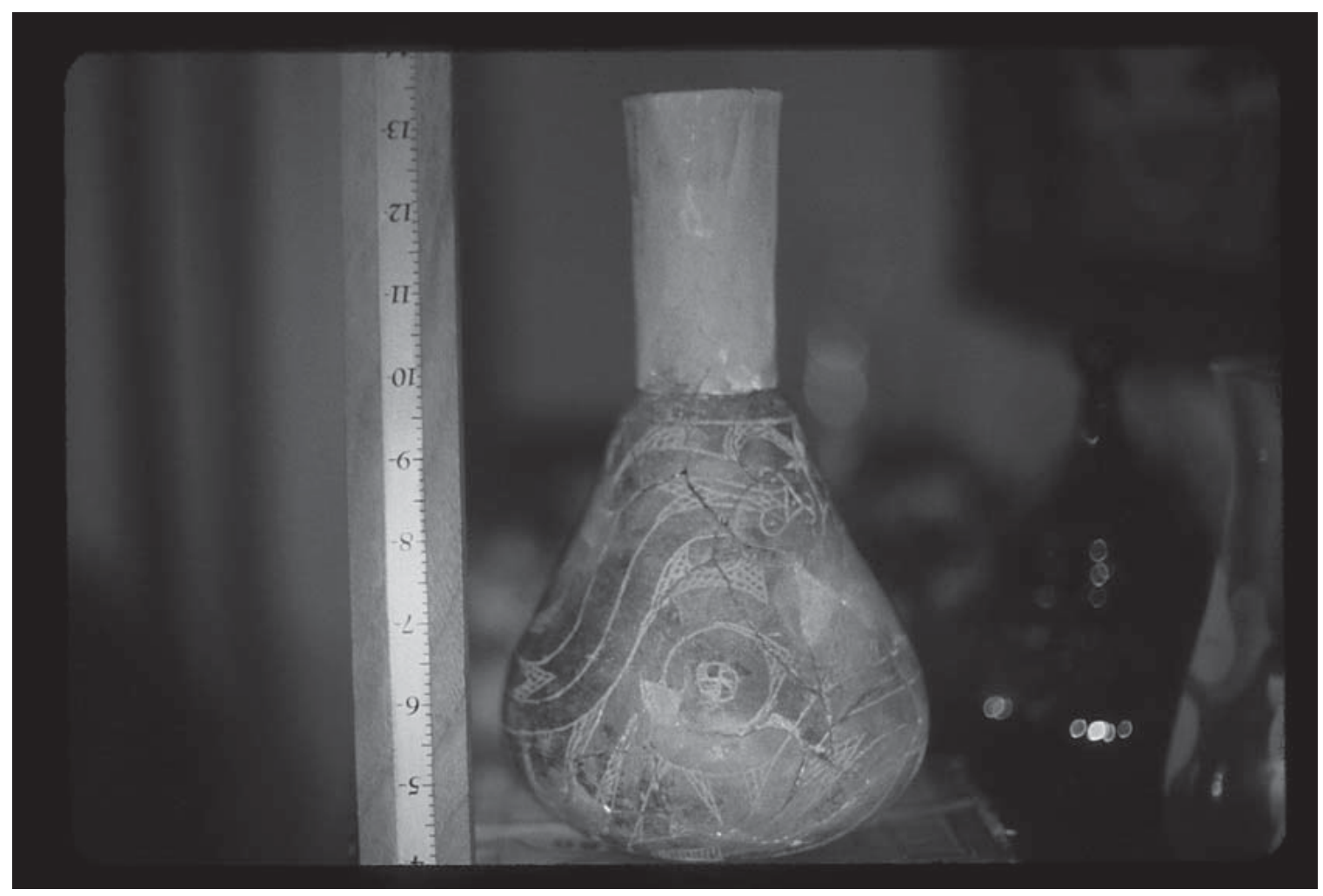

Figure 25. Graydon Adkins site (41UR21) vessel with engraved rattlesnake motif.

known, which is unfortunate, since this piece so closely resembles the example from the Washington Square Mound site in East Texas (see Figure 26).

The other example from the Red River is the stylized version (Figure 28) from the Holdeman site (41RR11) that is described by Perino (1995) as being Middle Caddoan in age. This particular vessel was found in Burial 17 in Cemetery No. 3. It was a shallow carinated bowl (see Perino 1995: Figure 10c).

Finally, in Hero, Hawk, and Open Hand, American Indian Art of the Ancient Midwest and South, an engraved bottle with interlocking serpent designs is part of a collection that is reported to be from southwestern Arkansas Caddo sites dating to ca. A.D. 1200-1500.(see Townsend 2004:248) The bottle shape, rattlesnake head, and chevron markings on the body (Figure 29) are very similar to the example from the Museum of the Red River (see Figure 27).

\section{Examples of Variation in Heads}

There are 15 different sites with engraved rattlesnake heads on ceramic vessels and/or sherds (Figure 30a-b). Ten examples have the "forked" tongue, although even the two heads at the Harold Williams site (41CP10) have the forked tongue drawn in two different ways. Seven examples have the eyes depicted in separate semicircles on the side of the head. Five have the head as a separate circle from the body. Two curious examples are from the Graydon Adkins site (41UR21), one dubbed the "king" snake because of its simulated "crown," and curved elements described by Bob Turner as "ice-tongs." Two of the more stylized versions are from Holdeman (41RR11), which seems to be an open mouth with a possible fang, and from Benson's Crossing (41TT110), 


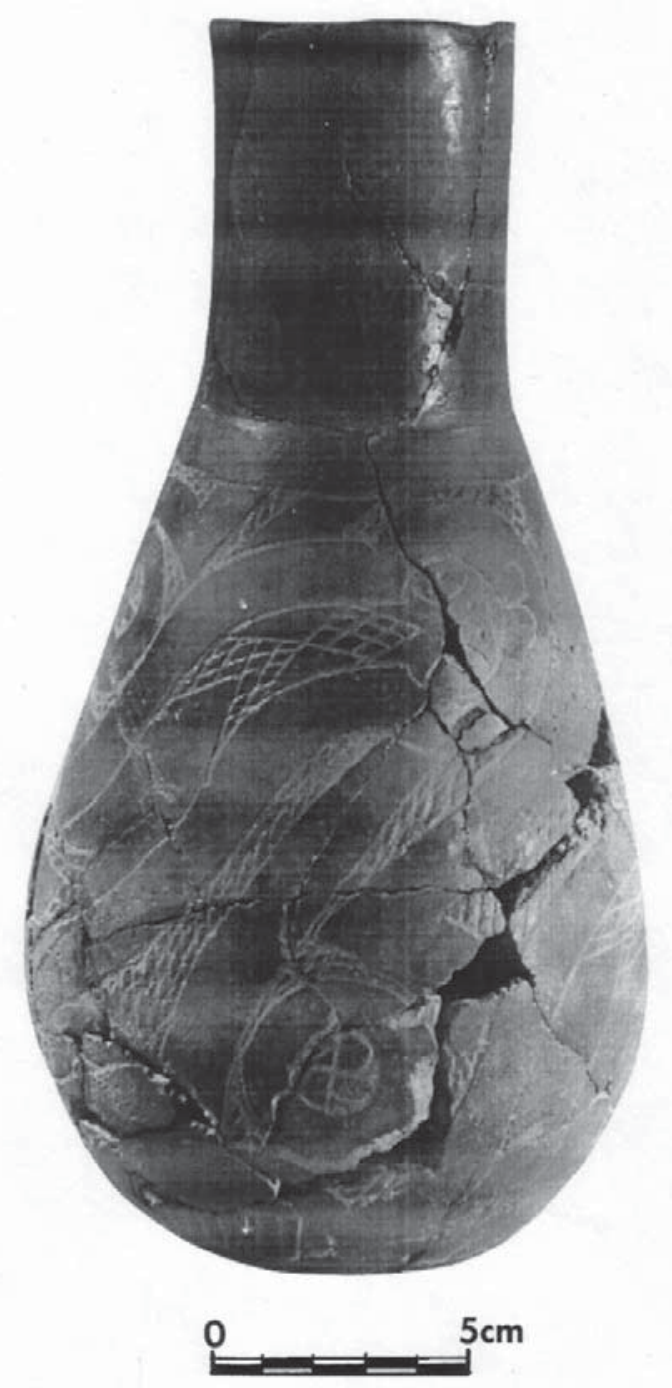

Figure 26. Bottle with canebrake rattlesnake motif, Feature 95 at the Washington Square Mound site (41NA49).

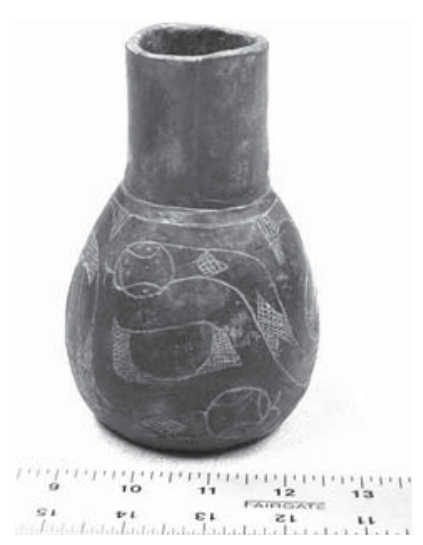

Figure 27. Museum of the Red River example of an engraved rattlesnake bottle. which only has the forked tongue element. And of course the folks at the Langford site (41SM197) had the forked tongue right but only had a single eye inside the body with the other two outside.

\section{Examples of Bodies}

Figure 31 illustrates 12 different examples of the body portion of the snake. The most common $(n=9)$ is the chevron design. The example from the Lake Clear site (41SM243) was the only engraved rattlesnake sherd with a diamond design. Other variations were the stylized example from the Holdeman site (41RR11) that had bands of straight lines and the example from the Langford site (41SM197) with a jointed body and cross-hatched panels.

\section{Examples of Tails/Rattles}

Figure 32 illustrates nine good examples of tails/rattles on the engraved rattlesnake designs. The vessel from the Avinger Rest Stop site (41CS132) was the only example that clearly showed the individual rattles and pear-shaped "button" of the rattler section of the tail. The example from the Washington Square Mound (41NA49) had overly developed rattles and to a lesser extent so did the example from the Harold Williams site (41CP10).

The other examples showed the tail/rattles as simply the end section as depicted by parallel opposing lines or crosshatching, although one example from the Pine Grove site (41HS826) had a chevron design. The example from the Museum of the Red River has two tails forming a circle,

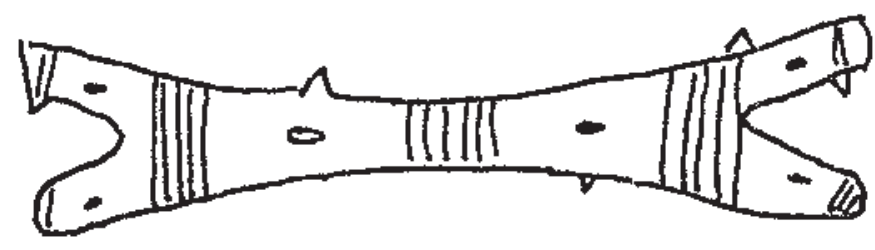

Figure 28. Holdeman site (41RR11) stylized rattlesnake motif. 


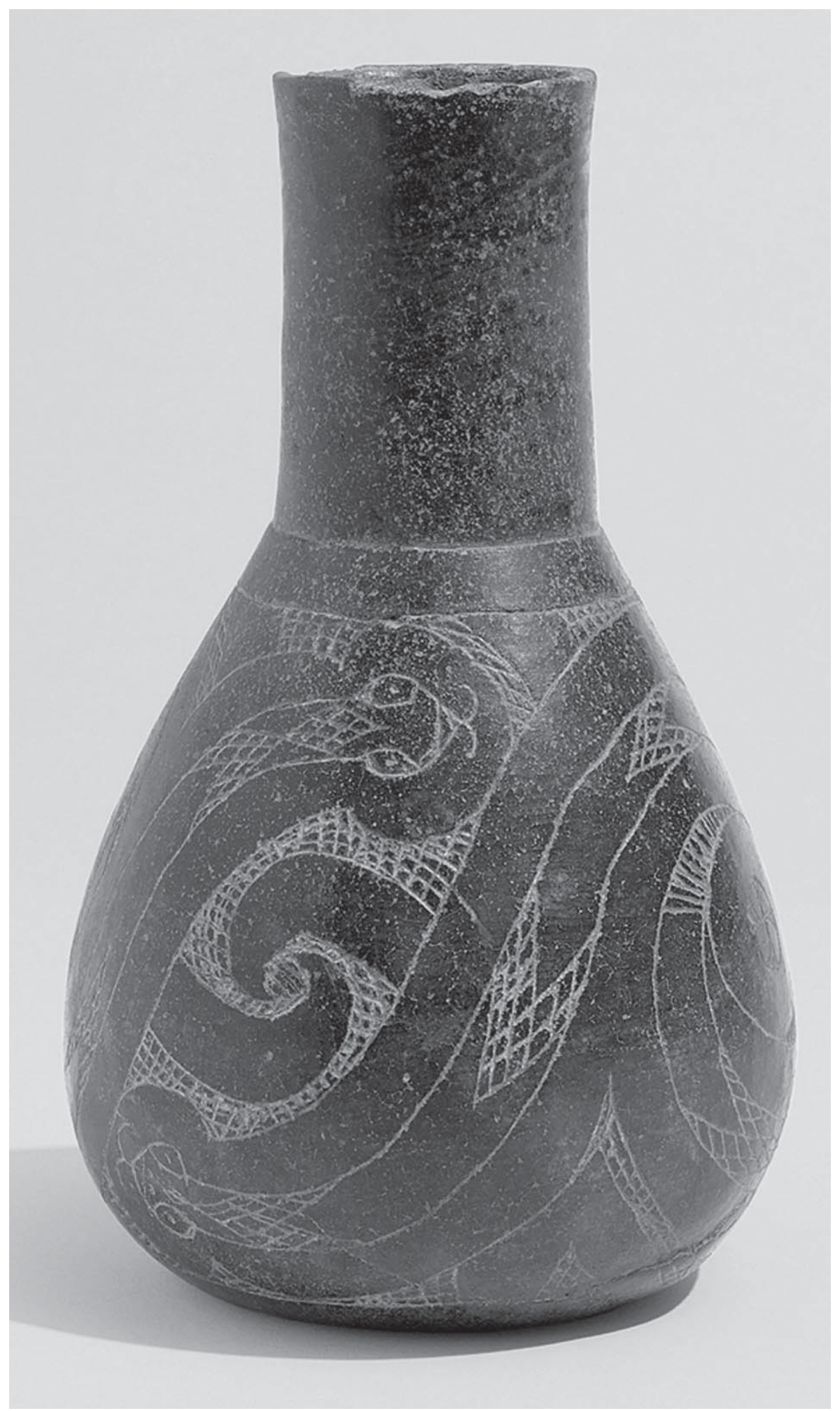

Figure 29. Engraved bottle with rattlesnake designs from Kinker collection, from Townsend and Walker (2004). 


\section{Cypress}

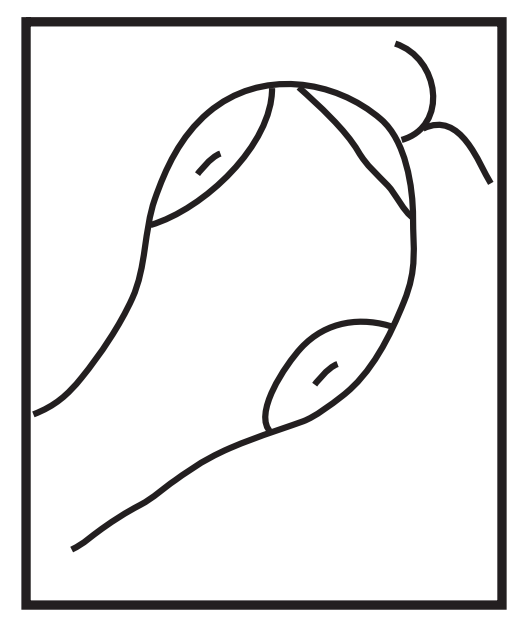

$41 \mathrm{HS} 826$

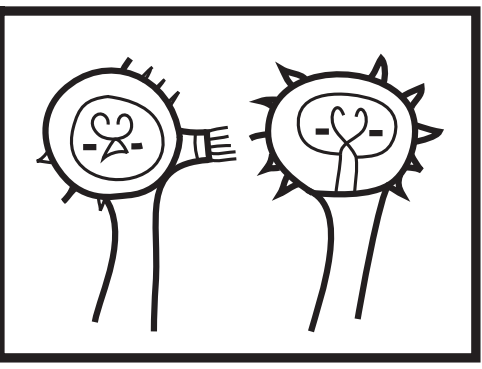

41UR21

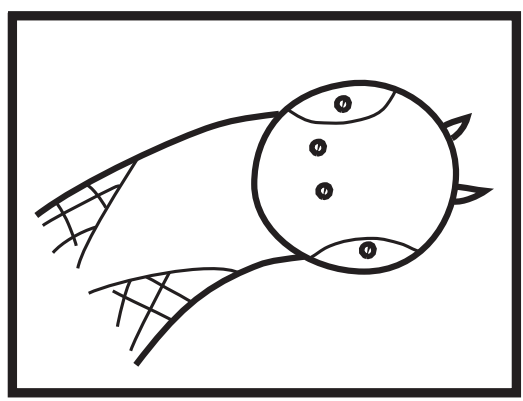

D Head Site

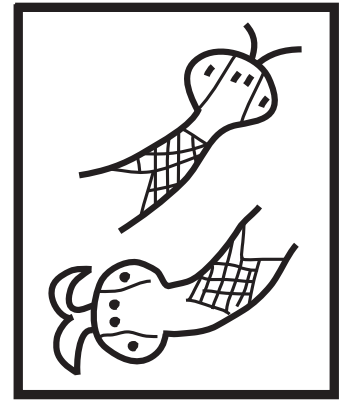

$41 \mathrm{CP} 10$

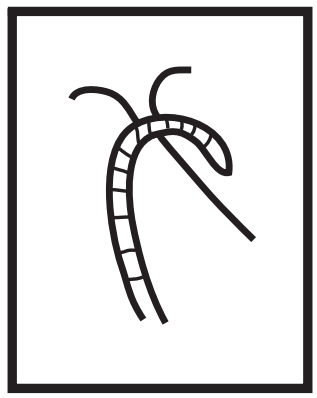

$41 \mathrm{TT} 110$
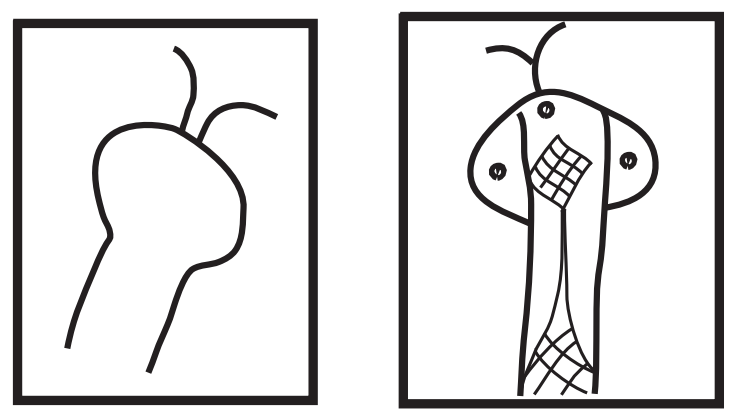

Kennedy

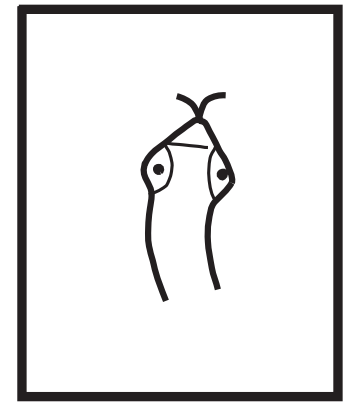

41UR3

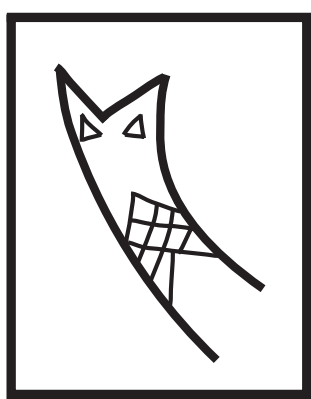

41CS132

$41 C P 71$

Figure 30a. Illustrations of rattlesnake heads by drainage: a, Big Cypress Creek sites; b, Sabine and Angelina River basin sites. 
Sabine

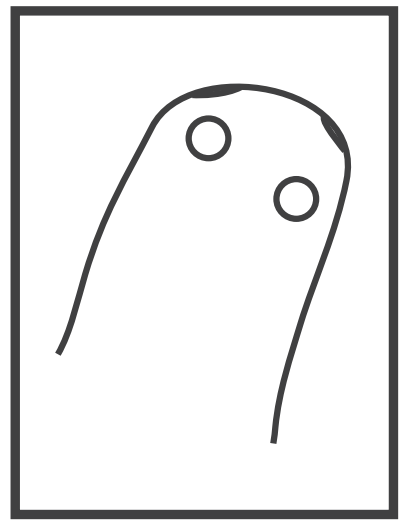

41SM243

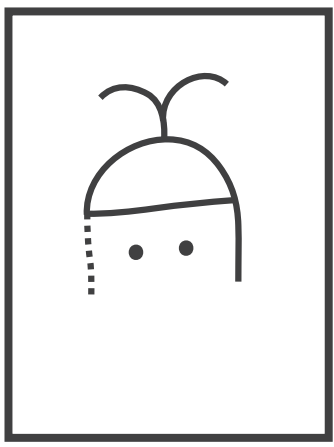

41RK214

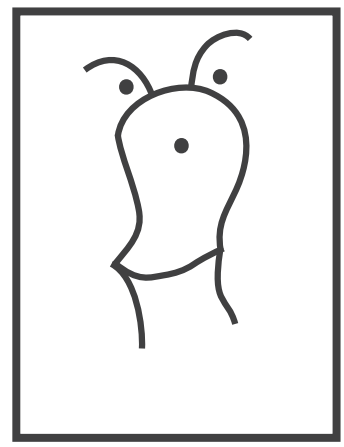

$41 \mathrm{SM} 197$

Angelina

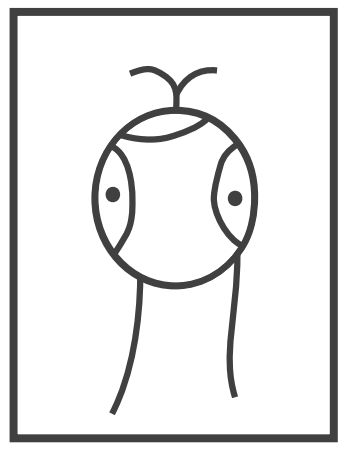

41NA219

Figure 30b. Illustrations of rattlesnake heads by drainage: a, Big Cypress Creek sites; b, Sabine and Angelina River basin sites. 


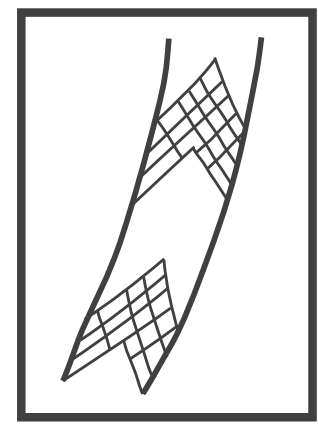

$41 \mathrm{HS} 826$

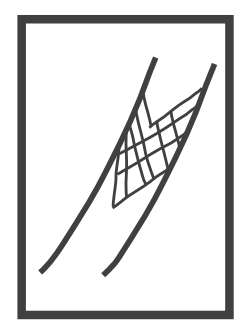

41UR21

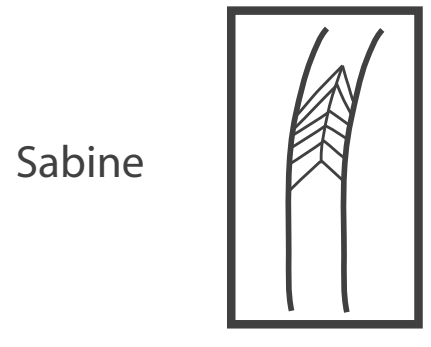

$41 \mathrm{SM} 243$

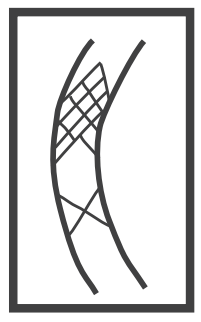

$41 \mathrm{CS} 132$

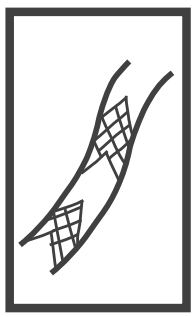

41UR3

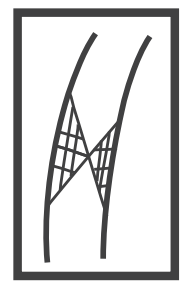

$41 \mathrm{SM} 243$

\section{Cypress}

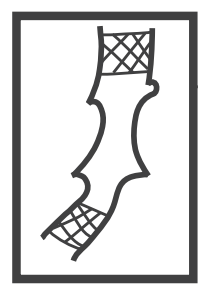

41SM197

Red River

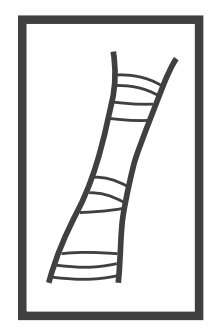

41RR1

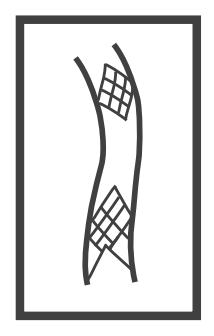

Museum of Red River

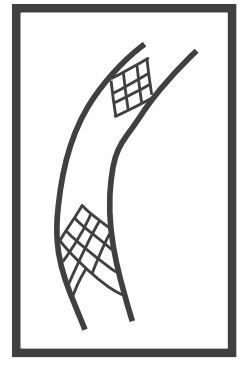

41NA49

Angelina

Figure 31. Illustrations of rattlesnake bodies by drainage. 
Tails

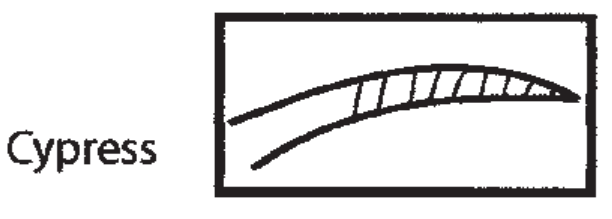

41UR21
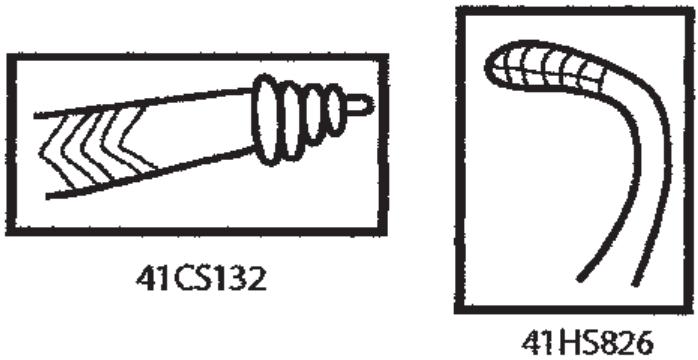

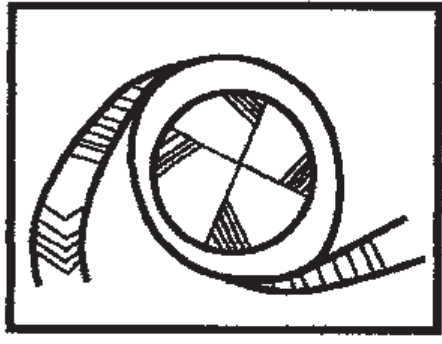

41H\$826

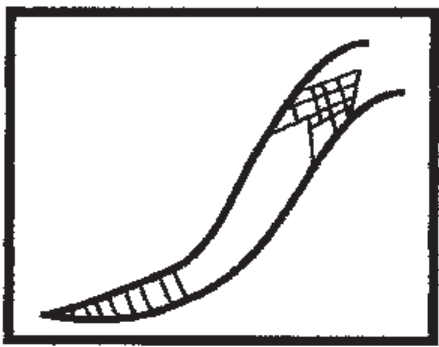

41CP71

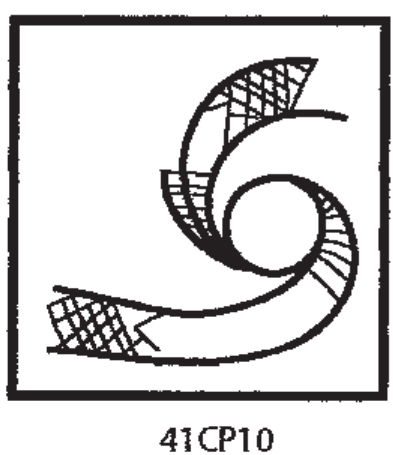

Sabine

415M243

Red River

Angelina

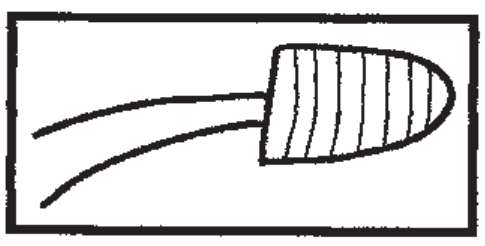

41NA49

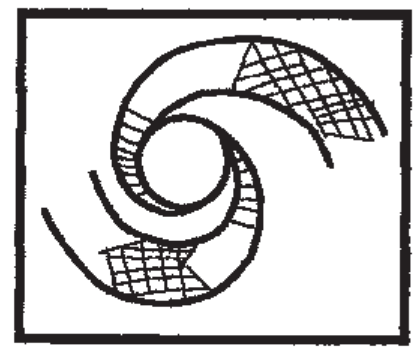

Museum

Red River

Figure 32. Illustrations of rattlesnake tails by drainage. 
part of an overall scroll effect, as did the example from the Harold Williams site (41CP10). The example from Harold Williams also shows two different ways of depicting the rattle section, one with parallel opposing lines, and its mate slightly enlarged and superimposed over the tail section.

\section{References Cited}

Corbin, James E.

1997 Snake Woman. La Tinaja (December 1997), p. 11.

Corbin, James E. and John P. Hart

1998 The Washington Square Mound Site: A Middle Caddo Mound Complex in South Central East Texas. Bulletin of the Texas Archeological Society 69:47-78.

Dixon, James R.

2000 Amphibians and Reptiles of Texas. Texas A\&M University Press, College Station.

Dorsey, George A

1905 Traditions of the Caddo. Publication No. 41. Carnegie Institution of Washington, Washington, D.C..

Duffield, Lathel F.

1964 Engraved Shells from the Craig Mound at Spiro, LeFlore County, Oklahoma. Memoir No. 1, Oklahoma Anthropological Society, Norman.

Galan, Rachel B.

1994 Caddo Mythology: Ethnohistorical and Archaeological Considerations. Mid-American Folklore 22(2):61-67.

Hart, John P.

1982 An Analysis of the Aboriginal Ceramics from the Washington Square Mound Site, Nacogdoches County, Texas. Master's thesis, Department of Anthropology, Northeast Louisiana University, Monroe.

Hatherly, Don T.,

1993 Soils Survey of Smith County, Texas. United States Department of Agriculture, Soil Conservation Service in cooperation with the Texas Agricultural Experiment Station and the Texas State Soil and Water Conservation Board.

Kleinschmidt, Ulrich K

1982 Review and Analysis of the A.C. Saunders Site (41AN19), Anderson County, Texas. Master's thesis, Department of Anthropology, The University of Texas at Austin.

Maloney, C. (editor)

1976 The Evil Eye. Columbia University Press, New York.

Mitchell, Sharon A.

2000 Data Salvage Project: Greasy Creek Study. MS on file, Texas Archeological Research Laboratory, The University of Texas at Austin.

Neff, Hector and Michael D. Glascock

2000 Compositional Variation in Caddoan and Other Ceramics from Northeastern Texas: Update on Results of Instrumental Neutron Activation Analysis. Missouri University Research Reactor, University of Missouri, Columbia.

Nelson, Bo and Mike Turner

1997 Middle Caddoan Sites in the Cypress Creek Drainage Basin. Journal of Northeast Texas Archaeology 10:1-11.

Perino, Greg

1995 The Dan Holdeman Site (41RR11), Red River County, Texas. Journal of Northeast Texas Archaeology 6:3-65. 
Perttula, Timothy K.

1999 Ceramic Evidence for Prehistoric Caddoan Trade and Exchange. Mini-NSF Grant Proposal on file at the Missouri University Research Reactor, University of Missouri, Columbia.

Perttula, Timothy K. and Bo Nelson, with contributions by J. Phil Dering, LeeAnna Schniebs, Robert L. Turner, Jr., Mark Walters, and Diane Wilson

2004 Archeological Investigations at the Shelby Site (41CP71) on Greasy Creek, Camp County, Texas. Special Publication No. 5. Friends of Northeast Texas Archaeology, Pittsburg and Austin.

Perttula, Timothy K., Diane E. Wilson, and Mark Walters

2000 An Early Caddoan Period Cremation from the Boxed Springs Mound Site (41UR30) in Upshur County, Texas. and a Report on Previous Archaeological Investigations. Journal of Northeast Texas Archaeology 12:31-71.

Rogers, Robert and Timothy K. Perttula

2004 The Oak Hill Village Site (41RK214), Rusk County, Texas. Document No. 030083. PBS\&J, Austin..

Sax B.

1990 The Frog king: On legends, fables, fairy tales and anecdotes of animals. Pace University Press, New York.

Swanton, John R.

1942 Source Material on the History and Ethnology of the Caddo Indians. Bulletin 132, Bureau of American Ethnology, Smithsonian Institution, Washington, D.C..

Thurmond, J. Peter

1990 Archeology of the Cypress Creek Drainage Basin, Northeastern Texas and Northwestern Louisiana. Studies in Archeology 5, Texas Archeological Research Laboratory, The University of Texas at Austin.

Townsend, Richard F. and Chester P. Walker

2004 The Ancient Art of Caddo Ceramics, In Hero, Hawk, And Open Hand: American Indian Art of the Ancient Midwest and South. Richard Townsend, editor. The Art Institute of Chicago in association with Yale University Press, New Haven and London.

Turner, Robert L.

1997 Observations on Four Probable Middle Caddo Cemeteries in Camp and Upshur Counties. Journal of Northeast Texas Archaeology 10:12-35.

Turner, Robert L. and James E. Smith III, with contributions by Timothy K. Perttula, Bo Nelson, Mark Walters, and Bobby Gonzalez

2003 The Harold Williams Site (41CP10) and the Texas Archeological Society Field School of 1967. Bulletin of the Texas Archeological Society 73:1-68.

Walters, Mark

1997 The Langford Site (41SM197), Smith County, Texas. Journal of Northeast Texas Archaeology 9: 38-41.

2005 A Profile in East Texas Archeology. Bulletin of the Texas Archeological Society 75:119-120.

Walters, Mark and Patti Haskins, with contributions by David H. Jurney, S. Eileen Goldborer, and Timothy K. Perttula 1998 Archeological Investigations at the Redwine Site (41SM193), Smith County, Texas. Journal of Northeast Texas Archaeology 11:1-38.

Walters, Mark and Patti Haskins

2000 The Bryan Hardy Site (41SM55), Smith County, Texas. Journal of Northeast Texas Archaeology 12:1-26.

Willey, Gordon R. and Philip Phillips

1958 Method and Theory in American Archaeology. The University of Chicago Press, Chicago. 